Research paper

\title{
The Blake Event recorded near the Eemian type locality - A diachronic onset of the Eemian in Europe
}

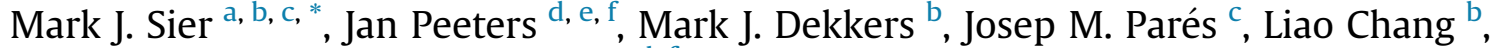 \\ Freek S. Busschers ${ }^{\text {e, Kim M. Cohen }}{ }^{\text {d, f, e , Jakob Wallinga }}{ }^{g}$, Frans P.M. Bunnik ${ }^{\text {e, }}$ \\ Wil Roebroeks ${ }^{a}$ \\ a Faculty of Archaeology, Leiden University, P.O. Box 9515, 2300 RA Leiden, The Netherlands \\ b Paleomagnetic Laboratory 'Fort Hoofddijk', Department of Earth Sciences, Faculty of Geosciences, Utrecht University, Budapestlaan 17, 3584 CD Utrecht, \\ The Netherlands \\ ${ }^{c}$ Centro Nacional de Investigación sobre la Evolución Humana (CENIEH), Paseo Sierra de Atapuerca 3, 09002 Burgos, Spain \\ d Department of Physical Geography, Faculty of Geosciences, Utrecht University, Heidelberglaan 2, P.O. Box 80115, 3508 TC Utrecht, The Netherlands \\ e Geological Survey of the Netherlands - TNO, Princetonlaan 6, P.O. Box 80015, 3508 TA Utrecht, The Netherlands \\ ${ }^{\mathrm{f}}$ Deltares, Unit Subsurface and Groundwater Systems, Princetonlaan 6, P.O. Box 85467, 3508 AL Utrecht, The Netherlands \\ ${ }^{g}$ Netherlands Centre for Luminescence Dating/Soil Geography and Landscape Group, Wageningen University, PO Box 47, 6700 AA Wageningen, \\ The Netherlands
}

\section{A R T I C L E I N F O}

\section{Article history:}

Received 22 October 2013

Received in revised form

2 March 2015

Accepted 14 March 2015

Available online 19 March 2015

\section{Keywords:}

Land-sea correlation

Last interglacial

MIS 5e

Paleomagnetism

Southern North Sea Basin

\begin{abstract}
A B S T R A C T
Multidisciplinary analysis including paleomagnetic, sedimentologic, sea-level change, luminescence dating and palynologic research was performed on a $25 \mathrm{~m}$ long orientated core taken at Rutten, close to Eemian key localities in the Netherlands. The main goal of our research was to test a possible delayed onset of temperate conditions in this region compared to Southern Europe, occurring within the Last Interglacial. The sediments revealed the presence of the paleomagnetic Blake Event in ca. $10 \mathrm{~m}$ of lowerdeltaic floodbasin sediments that contain a pollen record covering the Eemian. The position of the Blake Event in relation to the pollen stratigraphy concurs with the earlier studied Neumark Nord 2 site. Paleomagnetic correlation to core MD95-2042 off SW Iberia indicates ca. 5 kyr diachroneity between the pollen-based onset of temperate interglacial conditions between northern and southern Europe. The onset of the Eemian in north-western and central Europe (ca. $121.0 \mathrm{ka}$ ) post-dates the Marine Isotope Stage 6/5e transition by ca. $10 \mathrm{kyr}$. In addition, the Rutten data provide evidence for a relatively long duration of the Blake Event of at least 8 kyr. The late onset of the temperate conditions that define the base of the Eemian, imply that NW Europe with the Eemian type area is not the most suited region to define the beginning of the Last Interglacial and Late Pleistocene for global chronostratigraphic use.
\end{abstract}

() 2015 Elsevier B.V. All rights reserved.

\section{Introduction}

The stratigraphic term »Eemian « is in use as a local biostratigraphical zone in the type area in the central Netherlands and as a regional biostratigraphical zone across Europe. It is also in use as a formal regional chronostratigraphical unit more or less equivalent to the Last Interglacial in Europe and the North Atlantic, and as an informal (i.e. not ratified) global chronostratigraphical unit (Turner, 2002a). There is a notion that what is recognised as

\footnotetext{
* Corresponding author. Faculty of Archaeology, Leiden University, P.O. Box 9515, 2300 RA Leiden, The Netherlands.
}

E-mail address: marksier@gmail.com (M.J. Sier). the Eemian, has a different timing and duration in various places across northern and southern Europe (Kukla et al., 2002; Turner, 2002a; Tzedakis et al., 2003). Strictly speaking, if the Eemian is used as a chronostratigraphical unit, by definition it cannot be diachronic, while when used as a biostratigraphical zone it can be. In this sense the title of this paper is somewhat provocative. As long as the term Eemian is only used in and near its type area, a dual use for bio- and chronostratigraphical purpose is not that problematic. When biostratigraphy-independent dating and correlation results identify acclaimed chronostratigraphic correlations over larger distances to be diachronic (e.g. as suggested in Sier et al. (2011)) on the basis of paleomagnetic investigations on the Blake event), however, this is a problematic outcome. Any notion of serious 
diachroneity (i.e. in the order of a few thousands of years) concerning the onset of the Eemian requires rigorous testing at lastinterglacial locations across Europe, and preferably in the type area. Repeated tests then can either identify that assumptions underlying earlier chronostratigraphic correlations were wrong in hindsight, or that the independent dating methods are off. This paper performs such a test, for which opportunity arose with work on a new site in the Eemian type region in the central Netherlands.

This paper addresses the dating of the Eemian in the type area in the central Netherlands and the correlation and dating of the Eemian in adjacent regions (e.g. north-western and central Germany). Next, the implications for the correlation and dating of the "Eemian" and the Last Interglacial in areas further out in Europe are being discussed. Throughout the paper, »Eemian « is used where the term relates to biostratigraphic and chronostratigraphic use within the type area and adjacent areas in NW Europe (sites in Fig. 1), and " "Eemian" « is used where it considers biostratigraphical and chronostratigraphical correlative use in wider Europe and beyond (regardless of whether this past use has been informal or formal, and stratigraphically correct or not). The Eemian in its type area was first informally introduced by Harting (1874) to describe a Lusitanian mollusc-rich shallow-marine unit encountered near Amersfoort (The Netherlands; Fig. 1). After pioneering work by Jessen and Milthers (1928), the boundaries to define the Eemian are taken from pollen assemblage zones (Zagwijn, 1961). With regional modifications, this became in general use across NW Europe, both biostratigraphically and chronostratigraphically (Turner, 2000). The term "Eemian" became also in use to group temperate pollen assemblage zones in last-interglacial records in southern Europe. The European "Eemian" was often assumed to be fully equivalent to Marine Isotope Stage (MIS) 5e, implying a synchronous start and having the same duration. However, studies of washed-in pollen in core MD95-2042 off the Iberian coast have demonstrated a ca. $5 \mathrm{kyr}$ delay of the onset of the "Eemian" relative to the onset of MIS 5e, based on paired $\delta^{18} \mathrm{O}$ and pollen data; (Sánchez Goñi et al., 1999; Shackleton et al., 2002, 2003). A recent study at the NeumarkNord 2 (NN2) archaeological site in central Germany (Fig. 1), based on land-sea correlation making use of the paleomagnetic Blake Event, suggested a further delay of another 4-5 kyr to the onset of Eemian temperate conditions at higher latitudes (Sier et al.,
2011). If correct, such large time lags have significant consequences for views on the environmental development in the Last Interglacial across southwest, northwest and central Europe - besides suggesting chronostratigraphical mismatch between SW European "Eemian" and NW European Eemian. Furthermore, being able to position the Blake Event within Eemian pollen successions holds potential for the correlation of last-interglacial archaeological sites on a very high resolution absolute time scale (Sier et al., 2011).

Here, results are described that were obtained from an orientated, undisturbed core with Eemian sediments from the Netherlands. This research core (B15F1501) provides important new evidence to constrain the position of the Blake Event with respect to the north-western European Eemian pollen zonation. The core is located in the central Netherlands (Fig. 1, Rutten lies in the Noordoostpolder), where the lower Rhine delta was located during the Eemian interglacial (Peeters et al., 2015). The cored sediments are part of the fill of a ca. $70-\mathrm{km}$ wide last-interglacial shallow-marine embayment, where the Eemian (para)type localities of Amersfoort (Zagwijn, 1961; Cleveringa et al., 2000) and Amsterdam Terminal (Van Leeuwen et al., 2000; Beets and Beets, 2003; Beets et al., 2006) are also located in (Fig. 1). Some years ago, the latter site has been proposed as a location to host the Global Chronostratigraphical Section and Point for the Late Pleistocene (Gibbard, 2003; Gibbard and Cohen, 2008; Litt and Gibbard, 2008). The current status is that the proposal has been rejected and needs to be resubmitted if to be considered in the future (Head et al., 2013).

The main goal of this study was to test a possible delayed onset of temperate conditions in NW Europe, by retrieving a detailed paleomagnetic record of the Blake Event and correlating its position in relation to the Eemian pollen zonation and other stratigraphic signals in the type area, at a hereto suitable location near the Eemian type locality. Especially, relative age control on the start of the Blake Event vs. that of the Eemian is important as it enables a direct comparison with the previous findings at Neumark Nord 2 in Germany (Sier et al., 2011). A second goal is to better constrain the duration of the Blake Event in this region of Europe, as published durations are distinctly variable from $\sim 1 \mathrm{kyr}$ to over $7 \mathrm{kyr}$ (e.g. Bourne et al., 2012; Channell et al., 2012). A better constrained duration opens up the possibility for the Blake Event to be used as a geochronological marker, enabling inter-site comparisons of
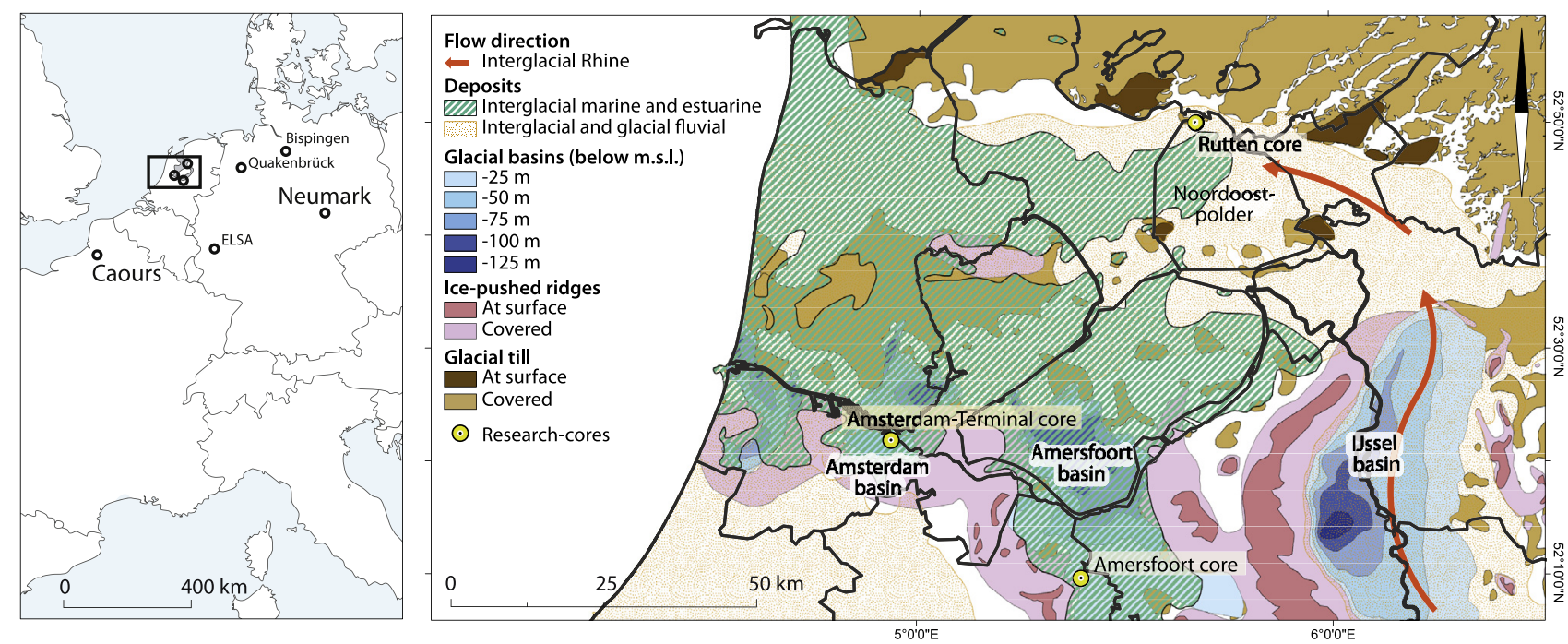

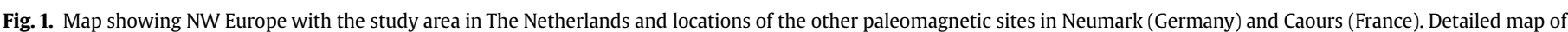

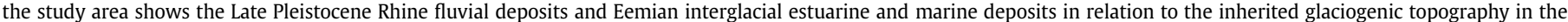

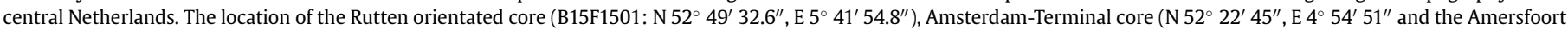
core are indicated (N 52 $9^{\prime}$ 36.7", E $5^{\circ} 2^{\prime}$ 0.7"). After Gunnink et al. (2013) and Peeters et al. (2015). 
14

M.J. Sier et al. / Quaternary Geochronology 28 (2015) 12-28
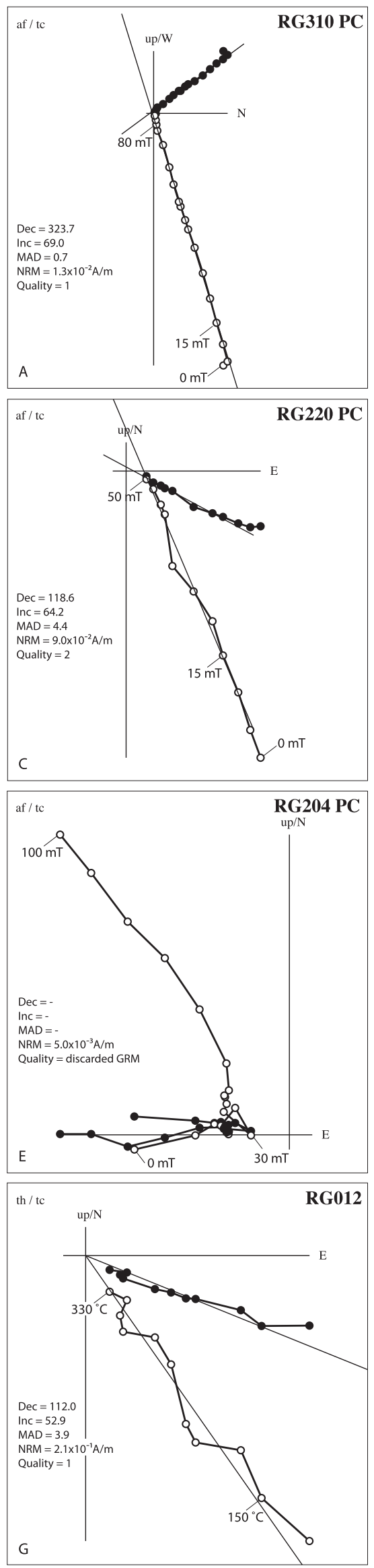
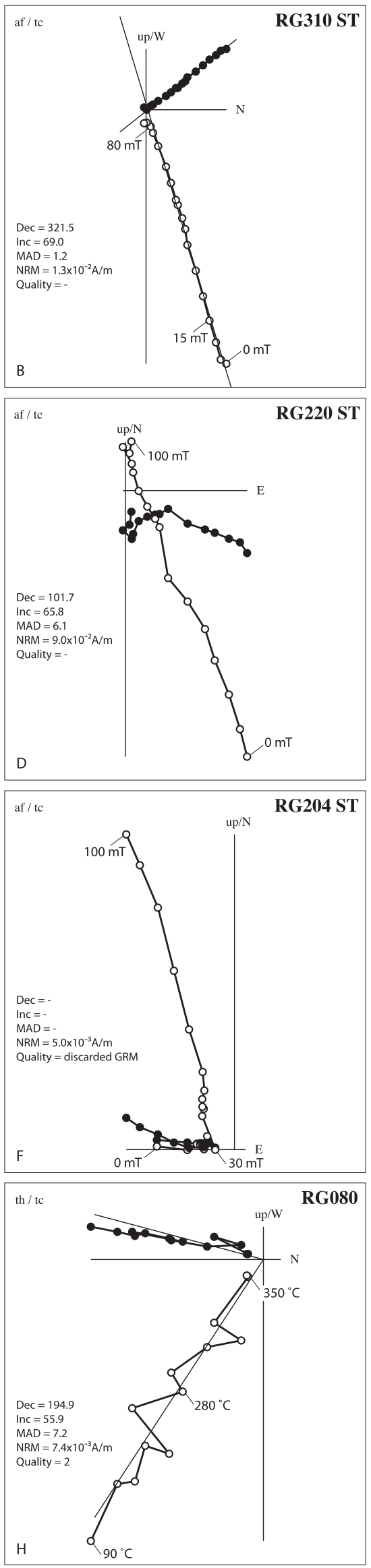


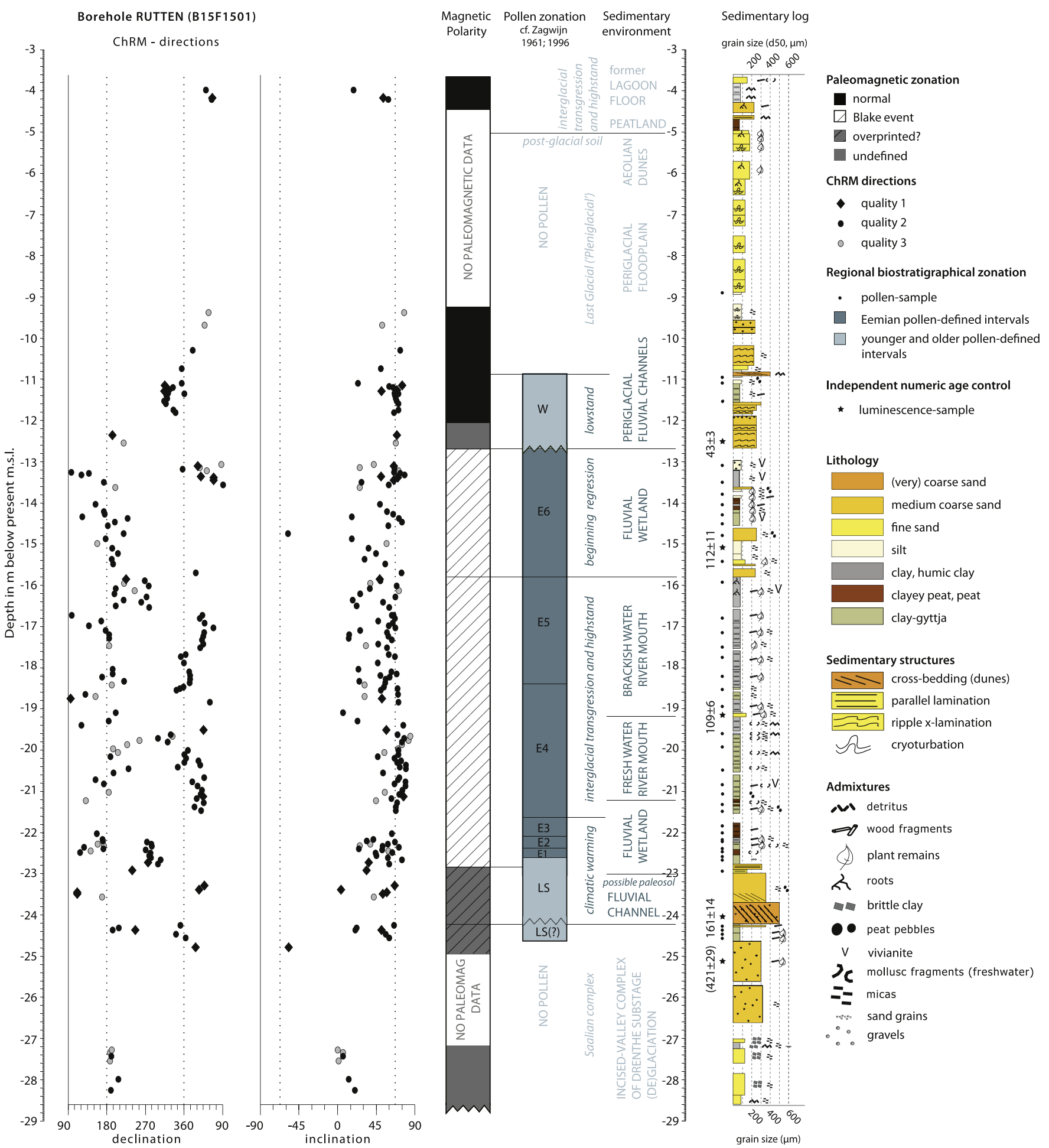

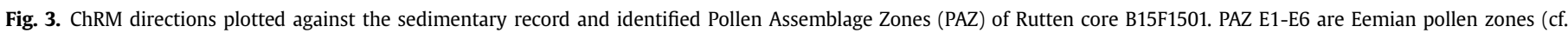
Zagwijn, 1961), W stands for Weichselian and LS for Late Saalian. Declination and inclination values are in degrees.

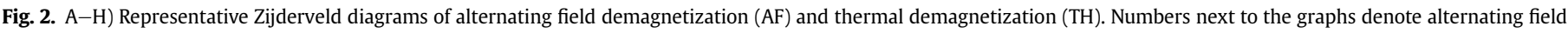

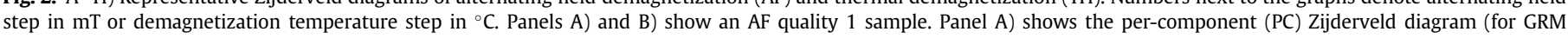

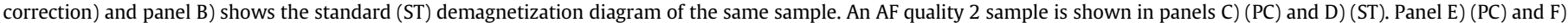

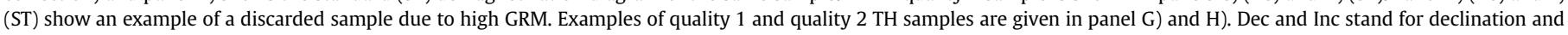
inclination in degrees. MAD is maximum angle of deviation. See main text for further explanations, for stratigraphic levels see SI Tables I and II. 
archaeological sites in high detail, within the Last Interglacial. Finally, the paleomagnetic directions from Rutten could provide new information on the geomagnetic nature of the Blake Event and the debate about the lack of fully reversed directions during the Blake Event in north-western Europe (e.g. Sier et al., 2011; Scholger and Terhorst, 2013).

\section{Geological and stratigraphic setting}

The Netherlands and adjacent parts of north-western Europe experienced strong geomorphological modification due to expansion and retreat of ice-sheets during the Middle Pleistocene (Passchier et al., 2010; Laban and van der Meer, 2011; Lee et al., 2012). The Saalian period in particular is of importance here, since the northern half of the Netherlands (including the research site) was covered by ice during the Drenthe Substage (e.g. Van Den Berg and Beets, 1987; Busschers et al., 2008), resulting in the formation of distinctive glacial morphology in the northern and central Netherlands (Fig. 1). This morphology surrounds and constrains the last-interglacial marine embayment that contains the deposits that host the Eemian type sections at Amsterdam and Amersfoort (Harting, 1874; Van Leeuwen et al., 2000; Zagwijn, 1961). In the embayment, the sedimentary contact of the Eemian transgression with its typical marine mollusc and palynological indicators, is well recognizable. The Eemian transgressive strata always overlie the glaciogenic stratigraphic levels of the Drenthe substage glaciation and deglaciation, and always underlie the periglacial stratigraphic levels of the Last Glacial (De Gans et al., 2000; Peeters et al., 2015). Importantly, the transgressive surface is a stratigraphic marker within the Eemian interglacial: a key finding of Zagwijn $(1961,1983)$ was that temperate conditions were established before the transgression began to affect the embayment area.

The series of ice-pushed ridges marking the Saalian maximum ice-front, basically define a central basin within the former icelimit. During the deglaciation, the river Rhine established a drainage route through the central basin. The Rhine inherited and (partly) infilled former subglacial topography as well as a large east-west oriented deglacial paleovalley (Fig. 1; Busschers et al., 2007, 2008; Peeters et al., 2015). Due to postglacial sea-level rise, the basin gradually transformed into a shallow-marine embayment. Due to its inland position within the North Sea Basin, the embayment recorded the last phases of transgression and the highstand. At Amersfoort and Amsterdam, on the south-western rim of the embayment, in the absence of a nearby major river mouth, the transgression and high-stand are recorded as tidal coastal environments. In the surroundings of the Rutten site (Rutten core in Fig. 1) on the rim of the embayment, lower-deltaic and estuarine conditions prevailed in proximity to the river Rhine (Fig. 1). The presence of a spatially well-recognisable and traceable transgressive surface, makes that the Rutten, Amersfoort and Amsterdam sites are all embedded in the same embayment and that each of these sequence are evidently of Eemian age. All other means of stratigraphic correlation of the Rutten site to the other localities in the type area, such as on relative sea-level history, palynology and through numeric dating are supporting secondary lines of stratigraphic correlation, crucial for the subdivision of the Eemian.

In the northeast of the embayment, the Late Saalian Rhine sediments are overlain by fine-grained and organic-rich, lowerdeltaic and estuarine sediments of Eemian and (partly) Weichselian Early Glacial age. In the direct surroundings of the Rutten core, hundreds of boreholes (available in the TNO-GSN subsurface database) show younger fluvial erosion to have truncated the top of the Eemian deposits (Peeters et al., 2015). The Rutten core was placed at a location where TNO-GSN data had shown that preservation of the fine-grained Eemian sediments was optimal (ca.
$10 \mathrm{~m})$. The sequence at Rutten indicates the locality to have received fine-grained Rhine flood deposits throughout the entire time period of interest, i.e. starting in the Late Saalian after icesheet disintegration, and continuing into the Eemian interglacial, also during transgression and high-stand, although Rhine influence decreased with regression at the very end of the Eemian. The continuous delivery of fine-grained sediment from the nearby river and its trapping in a distal flood basin setting, imply that the lithology and facies of the Rutten core are well suited for collecting paleomagnetic data throughout the Eemian (Section 4.1; Fig. 3; SI). Compared to the type locality at Amersfoort (Zagwijn, 1961), where the Eemian spans ca. $15 \mathrm{~m}$ of sequence with, however, at least four sedimentary breaks (Cleveringa et al., 2000), the Eemian interval in the Rutten core has a depositional record that is more continuous. At the Amsterdam-Terminal type site (Van Leeuwen et al., 2000), the Eemian interval spans a much greater thickness of ca. $30 \mathrm{~m}$. Of this interval, ca. $18 \mathrm{~m}$ comprise shallow marine sediments deposited during the high-stand period in the later part of the Eemian, containing crumbly portions of mixed composition, which represent sedimentary discontinuities in this part of the sequence. This is in strong contrast to the Rutten core were steady sediment delivery by the Rhine made that shifts in depositional environment related to transgression and highstand were smaller. Paleomagnetic investigation on the un-orientated core from Amsterdam-Terminal had been attempted (Van Leeuwen et al., 2000), but was necessarily restricted to interpretation of the inclination record. Further, only alternating field demagnetization was utilized to uncover the characteristic remanent magnetization component (see below). The Amsterdam-Terminal type site is now built over and could not be revisited to obtain fresh research material. Some 15 years later, more advanced methods are available that were deployed on the orientated Rutten core.

\section{Methods}

\subsection{Coring and sampling}

The $25 \mathrm{~m}$ long Rutten core (B15F1501) was retrieved with a sediment-catcher equipped Nordmeyer core-sampler. The coresampler was modified to produce core segments with known (magnetic north) orientation. The core-segments $(1 \mathrm{~m}$ long and $10 \mathrm{~cm}$ diameter) were sealed airtight with paraffin and kept in cool storage $\left(<5{ }^{\circ} \mathrm{C}\right)$ at the TNO-GSN core facility. Here, upon arrival, the core-segments were split in halves, were photographed, and described according to the TNO-GSN standard (SBB 5.1: Bosch, 2000).

Paleomagnetic samples for alternating field (AF) demagnetization were collected from one core half with dedicated Perspex sample containers. Custom-made quartz-glass sample containers were used for thermal $(\mathrm{TH})$ demagnetization samples. These sample containers all have standard paleomagnetic dimensions (25 mm diameter and $22 \mathrm{~mm}$ length) and were gently pushed into freshly prepared core sections. A total of 252 samples were taken, $118 \mathrm{TH}$ and $134 \mathrm{AF}$ samples. TH and AF samples were taken alternatingly as much as possible to get an even distribution of the two methods. Measurements were done within one week after sample retrieval and within two weeks after retrieval of the core to ensure the freshness of the sample material.

Samples for palynological analysis were taken from predominantly fine-grained, organic-rich sediments from this core-half as well. The remaining other half of the core was sampled under subdued red-orange light conditions for luminescence dating. Luminescence samples were taken from (relatively) homogeneous sediment sections (see Fig. 3 for sample levels), of which about 400-800 g of sediment per sample was transferred into an opaque black plastic bag and sealed. The samples were transported to the 
Netherlands Centre for Luminescence-dating for further sample preparation and age determination.

\subsection{Pollen analysis and biostratigraphic zonation}

Palynological analysis in this study was primarily used as a biostratigraphic zonation tool in order to correlate the Rutten record to those of Amersfoort and Amsterdam-Terminal (Fig. 1). Pollen analysis was performed on 40 samples derived from mostly clayey, gyttjaic and peaty intervals in the Rutten core. Samples were prepared following standard procedures: peptization with $\mathrm{Na}$ pyrophosphate $\left(15 \mathrm{~g} / \mathrm{dm}^{3}\right.$ ), sieving (250 and $7 \mu \mathrm{m}$ mesh-size), $\mathrm{HCl}$ (30\%) rinsing, acetolysis (9:1 ratio of $\left.\left[\mathrm{CH}_{3} \mathrm{CO}\right]_{2} \mathrm{H}: \mathrm{H}_{2} \mathrm{SO}_{4}\right)$ and heavy liquid density separation (sodium-polytungstate with a specific gravity $2.1 \mathrm{~kg} / \mathrm{dm}^{3}$ ). Residues were mounted in glycerine on glass slides for microscopic analysis.

The complete percentage pollen diagram is provided as part of the Supplementary Information (SI Fig. 1). The diagram distinguishes the Eemian Pollen Assemblage Zones (PAZ), based on relative abundance of diagnostic taxa. These zones are labelled PAZ E1-E6 following the standard scheme for the Eemian type area. With these assemblage zones, and building on chronostratigraphical correlation of the type sites in the Netherlands to an annual-laminated sequence relatively nearby in NW Germany (Bispingen, Quakenbrück, Fig. 1; Müller, 1974; Turner, 2002b), a floating relative chronology for the Eemian of the study area has been established (e.g. Cleveringa et al., 2000: their Fig. 11; Van Leeuwen et al., 2000: their Fig. 2). This chronology was also applied to the Rutten site.

PAZ E1 to E6 are distinguished based on regional vegetation developments seen in tree pollen mainly. PAZ E1 to E3 mark the establishment of a temperate forest through pre- and earlytemperate stages of pioneer succession (Betula, then Pinus, then Quercus; in conjunction with changes in Ulmus and Corylus), in stages that typically follow each other up within short time (within a few centuries). These transitions did indeed proceed quick (e.g. Turner, 2002b) in NW Europe, in the analogous situation of the early Holocene and in that of the Eemian, as confirmed in annual-laminated sequences (Müller, 1974). Next, PAZ E4 and E5 mark changes in the composition of prevailing temperate forests. PAZ E4 has the thermophilous trees Corylus and Quercus both well established, and Taxus rising and peaking. PAZ E5 shows Carpinus rising and peaking, with Taxus disappearing and Corylus and Quercus continuing in presence. These are developments through a series of stages that each took longer time to commence and proceed. The base of PAZ E6 associates to a deterioration of temperate forests to a boreal forests, with the species Quercus, Corylus and Carpinus disappearing, Pinus and Picea being dominant and Abies occurring in smaller percentages. Evidently, these variations in regional pollen signal were searched for in the Rutten core to define zonations according to the standard scheme for the Eemian (Zagwijn, 1961, 1996).

On top of this expression of mainly dry-land forest signal, the pollen diagrams reflect variations in local wet-land vegetation; in fluvial settings such as at Rutten they reflect also in-wash of hinterland pollen. The latter affects the pollen palynological record of the Rutten core, which has urged us to restrain ourselves from proposing highly detailed palynological zonations and overly specific correlations to the Amersfoort and Amsterdam-Terminal type locations. Some $60 \mathrm{~km}$ upstream of the Rutten site, Busschers et al. (2007) described latest Saalian, Eemian and Weichselian pollen records from the fully fluvial low-land setting of the IJssel basin (Fig. 1) that support the notion of in-wash of pollen and that characterize the vegetation in the immediate fluvial hinterland.

We note that in the Rutten core, the palynological indications for nearby transgressive and marine high-stand conditions are also established independent from the standard PAZ schemes; they are based on indications from local vegetation and from in-wash of non-pollen indicators. The availability of a PAZ-tied relative sealevel history for the central Netherlands' embayment in the Eemian (Zagwijn, 1983, 1996) makes that site-to-site correlations based on relative sea-level indicators can be verified with pollen associations, and vice-versa. This was used to correlate subintervals of the Eemian in the Rutten core to the floating PAZ-annual lamination chronology.

\subsection{Luminescence dating}

Samples for luminescence dating were split in two parts upon arrival at the Netherlands Centre for Luminescence dating. One subsample was used to determine the dose-rate using highresolution gamma-ray spectrometry. For this purpose the sediment is dried, ground and moulded with wax to a puck that was measured on a gamma-spectrometer for at least $24 \mathrm{~h}$. Activity concentrations of ${ }^{40} \mathrm{~K}$ and several nuclides of the $U$ and Th decay chains are converted to dose rate, taking into account effects of moisture ( $20 \pm 3 \%$ by weight for sandy samples, $30 \pm 5 \%$ by weight for loamy samples), the contribution by cosmic rays, and the contribution from internal $\mathrm{K}$ and $\mathrm{Rb}$ in the $\mathrm{K}$-feldspar grains used for analysis (internal dose rate estimated to be $0.77 \pm 0.08 \mathrm{~Gy} / \mathrm{ka}$; Kars et al., 2012).

The other subsample is prepared for equivalent dose determination. These samples are wet-sieved to obtain a fraction of $180-212 \mu \mathrm{m}$ and were then treated with $\mathrm{HCl}$ and $\mathrm{H}_{2} \mathrm{O}_{2}$ to remove carbonates and organic matter respectively. A purified extract of $\mathrm{K}-$ rich feldspar grains was obtained through density separation using sodium-polytungstate heavy liquid at $2.58 \mathrm{~kg} / \mathrm{dm}^{3}$. This sediment fraction was further cleaned and etched using $10 \% \mathrm{HF}$, and subsequently rinsed with $\mathrm{HCl}$. A Risoe TL/OSL DA 20 reader was used for luminescence measurements. This apparatus is equipped with infrared diodes for stimulation $(870 \mathrm{~nm})$ and a $\mathrm{Sr} / \mathrm{Y}$ beta source for irradiation. A LOT/Oriel D410/30 interference filter was used to select the K-feldspar emission around $410 \mathrm{~nm}$.

Luminescence ages were obtained by novel post-infrared infrared stimulated luminescence (pIRIR 290 ) dating methods, applied to K-feldspar mineral extracts. This method was chosen as most of the samples were too old for reliable quartz OSL dating due to saturation of the OSL signal at relatively low doses (Wintle and Murray, 2006). The pIRIR 290 Single-Aliquot Regenerative (SAR) protocol (Thiel et al., 2011) avoids issues with signal instability (anomalous fading) and has been shown to yield meaningful results for similar lithologies (Buylaert et al., 2012; Kars et al., 2012). Parameters used were a $60 \mathrm{~s}$ preheat at $320{ }^{\circ} \mathrm{C}$, infrared bleach for $100 \mathrm{~s}$ at $50^{\circ} \mathrm{C}$, and pIRIR stimulation for $100 \mathrm{~s}$ at $290^{\circ} \mathrm{C}$. At the end of each SAR cycle, the signal was reset by $40 \mathrm{~s}$ exposure to infrared at $330{ }^{\circ} \mathrm{C}$. Performance of this protocol was tested using a doserecovery experiment (average dose-recovery ratio: $1.05 \pm 0.03$; $\mathrm{n}=12$ ), and stability of the pIRIR 290 signal was confirmed using a fading experiment (fading rate $\mathrm{g}_{2 \text { days }}=1.15 \pm 0.16 \%, \mathrm{n}=15$ ). No correction for fading was made as experiments on infinite-age samples have shown that the pIRIR 290 signal is not affected by fading during geological storage (Kars et al., 2012; Thiel et al., 2011). The results of luminescence dating are reported with errors indicating the 1-sigma (68\%) uncertainty, including all systematic and random uncertainties in both equivalent dose and dose rate estimation.

\subsection{Paleomagnetism and rock magnetism}

Stepwise progressive thermal demagnetization of the natural remanent magnetization (NRM) was performed with an ASC 
thermal demagnetizer (residual field $<20 \mathrm{nT}$ ) at CENIEH, Burgos (Spain). Maximum demagnetization temperature was $600{ }^{\circ} \mathrm{C}$. The remaining NRM after each step was measured with a SRM 755 helium free DC-SQUID (direct current superconducting quantum interference device; 2G Enterprises (California, USA)) magnetometer (instrument sensitivity $3 \times 10^{-12} \mathrm{Am}^{2}$, typical sample NRM intensities were at least a couple of orders of magnitude higher) with a low-field environment at the sample loading position. Before measuring, samples were put in a shielded environment for at least $30 \mathrm{~min}$. Alternating field demagnetization was done in 16 steps up to $100 \mathrm{mT}$ at the paleomagnetic laboratory of Utrecht University (The Netherlands). The instrument's sensitivity is $3 \times 10^{-12} \mathrm{Am}^{2}$. The instrument set-up is housed inside a magnetically shielded room (residual field $<200 \mathrm{nT}$ ), the robotized interface for field regulation and sample manipulation was built in-house. Up to 96 samples contained in dedicated cubic holders (edge $30 \mathrm{~mm}$ ) are loaded onto a sample plateau and the robot subsequently loads them in batches of eight onto a tray. AF samples were processed fully automatically with the so-called 'three position protocol' that compensates for the magnetic moment of the transport tray. Greigite $\left(\mathrm{Fe}_{3} \mathrm{~S}_{4}\right)$ that regularly occurs in organic-rich sediments often shows gyroremanent magnetization (GRM) during $A F$ demagnetization. To compensate for possible GRM, AF samples were processed with the so-called 'per component' protocol (Dankers and Zijderveld, 1981; Stephenson, 1993), in addition to the regular AF demagnetization. This was done for AF levels $\geq 30 \mathrm{mT}$.

The Characteristic Remanent Magnetization (ChRM) was typically determined by the steps between 280 and $340{ }^{\circ} \mathrm{C}$ ( 6 steps), occasionally starting at $150^{\circ}$ and continuing up to $480{ }^{\circ} \mathrm{C}$ (SI Table I). ChRMs from AF demagnetized samples were all determined above $10 \mathrm{mT}$ and mostly between 10 and $50 \mathrm{mT}$ (SI Table II). ChRM directions were calculated using least-squares principal component analysis (Kirschvink, 1980) on at least four steps. According to common practice, line fits for TH samples were anchored to the origin. The general trend of the ChRM component is then better appreciated. Line fits of AF samples were not anchored to the origin because this resulted in visually poor fits with unrealistically large MAD (maximum angle of deviation) angles when compared to line fits through the same data points without forcing through the origin.

Three quality labels were defined for the ChRM directions. AF demagnetization diagrams of which both 'per component' (Dankers and Zijderveld, 1981; Stephenson, 1993) and standard AF measurements showed hardly or no GRM indication and with an endpoint close to the origin, were labelled quality 1 (Fig. $2 \mathrm{~A}$ and $\mathrm{B}$ : MAD maximum $=11.3^{\circ}, 9$ out of $134 \mathrm{AF}$ samples). A quality 2 label was given to diagrams with a slight GRM in the standard diagrams, which could be corrected for by per component protocol and an endpoint close to the origin (MAD maximum $=14.8^{\circ}$, Fig. $2 \mathrm{C}$ and $\mathrm{D}$, 76 out of $134 \mathrm{AF}$ samples). ChRMs with a MAD $>15^{\circ}$ were given a quality of 3 ( 2 out of 134 AF samples). All diagrams with a GRM that could not be corrected for by the per component protocol or with a too strong GRM in the standard measurement protocol were not considered in the interpretation (examples in Fig. 2E and F: 47 out of the 134 AF samples). Only quality 1 and quality 2 samples were used for the interpretation of the magnetostratigraphy (see Fig. 2 for examples).

TH demagnetized quality 1 samples have clear ChRM directions with endpoints close to the origin (Fig. 2G: 12 out of 118 TH samples), whereas quality 2 samples have well-defined ChRM directions but endpoints were slightly off the origin (Fig. $2 \mathrm{H}$ : 49 out of $118 \mathrm{TH}$ samples). Quality 3 samples are based on just four data points and/or have MADs above $15^{\circ}$. The ChRM directions of quality $3 \mathrm{TH}$ samples were calculated but not used for the interpretation (25 out of $118 \mathrm{TH}$ samples). All other samples and all great circle trajectories were not included in the magnetostratigraphic interpretation (32 of $118 \mathrm{TH}$ samples).

Samples that were submitted to Anhysteretic Remanent Magnetization (ARM) and Isothermal Remanent Magnetization (IRM) measurements had first their NRM AF demagnetized. AF demagnetization (standard and per component), ARM and IRM acquisition was done with the robotized 2G DC-SQUID magnetometer. Programme controlled, it slides through the magnetometer and demagnetization coils that are used for the ARM acquisition (a bias field coil provides the asymmetry in the field which was set at $38 \mu \mathrm{T}$ ). Standardization took place by scaling to mean zero with a standard deviation of 1 . Finally, IRM acquisition curves were determined for all these samples with 60 steps up to a peak IRM field of $700 \mathrm{mT}$. This was done with a pulse-field coil, interfaced with the robotized magnetometer set-up. IRM acquisition curves were subjected to Cumulative Log Gaussian (CLG) component analysis (Kruiver et al., 2001). Prior to the IRM acquisition the samples were AF demagnetized at $300 \mathrm{mT}$ peak field with the final demagnetization axis parallel to the IRM pulse field direction to force the shape of the subsequently measured IRM acquisition curves as much as possible conform a CLG shape for most meaningful fits (cf. Egli, 2004; Heslop et al., 2004). After fitting of the data the different coercivity components can be recognised by their saturation IRM (SIRM), remanent acquisition coercive force $\left(\mathrm{B}_{1 / 2}\right)$ and dispersion parameter (DP) (Kruiver et al., 2001).

Hysteresis loops, back-field demagnetization, and first-order reversal curves (FORCs) were measured using a MicroMag alternating gradient magnetometer (Model M2900, paleomagnetic laboratory, Utrecht University; noise level $2 \times 10^{-9} \mathrm{Am}^{2}$ ). Hysteresis loops were measured between -1 and $+1 \mathrm{~T}$ with a field increment of $5 \mathrm{mT}$ and an averaging time of $150 \mathrm{~ms}$. Back-field demagnetization curves ( $250 \mathrm{~ms}$ waiting time) started with a saturation at $1 \mathrm{~T}$ and were acquired with logarithmic field increments with an averaging time of $150 \mathrm{~ms}$ as well. Hysteresis parameters, including the saturation magnetization $\left(M_{S}\right)$, the saturation remanent magnetization $\left(\mathrm{M}_{\mathrm{rs}}\right)$ and coercivity $\left(\mathrm{B}_{\mathrm{c}}\right)$ were determined after paramagnetic slope correction. High-resolution FORC diagrams (Pike et al., 1999; Roberts et al., 2000) were obtained by measuring $~ 500$ FORCs with maximum applied fields of $1 \mathrm{~T}$, field increments of $0.5 \mathrm{mT}$. FORC diagrams were calculated using a program written by T.A.T. Mullender (paleomagnetic laboratory, Utrecht University). This software package does not consider the FORC distributions close to the vertical axis to avoid uncertain interpretation for inherently incomplete FORC grids in this region of the diagrams. A smoothing factor (SF) of 5 (Roberts et al., 2000) was used to calculate all the FORC diagrams.

\section{Results}

\subsection{Integrated sedimentary and biostratigraphical description}

The basal unit in the Rutten record ( $-28.6 \mathrm{~m}$ to $-27 \mathrm{~m}$ below mean sea-level; m.s.l.) is characterized by fine-grained sands with brittle clay fragments. These sands were most likely deposited in a floodbasin setting. Upward in the record between $-27 \mathrm{~m}$ and $-23.0 \mathrm{~m}$ m.s.l., coarse-grained, cross-bedded gravelly sands are present, which are interpreted as channel belt deposits of the paleovalley complex of the Drenthe Substage deglaciation. Pollen material collected from a gyttjaic-interval (ca. $-24.4 \mathrm{~m} \mathrm{m.s.l.)}$ within these coarse-grained sediments showed the presence of herb and heathland vegetation (SI Fig. 1), which is characteristic for the Late Saalian (PAZ LS in Fig. 3: Zagwijn, 1961). The upper 1-2 m of this coarse-grained unit is characterized by notable iron-oxide precipitation. The iron-oxide precipitation is most likely caused 
by the dispersion of ferrous iron-containing groundwater originating from the southern rim of the glacial till plateau that was positioned directly north of the Rutten core, a situation analogous to the settings in the Holocene (Fig. 1). The top of this level represents a paleosurface, and part of the iron-oxide precipitation might represent a paleosol from just before the onset of the Eemian interglacial.

Overlying this coarse-grained unit, a medium to fine-grained layered sand-layer of a few decimeters thick was found (Fig. 3), marking more quiet fluvio-hydraulic conditions. From $-22.8 \mathrm{~m}$ m.s.l. upward, the sediments change to layered peats and freshwater mollusc-fragments containing clayey-gyttja, deposited in a tranquil fluvial wetland environment. Here, the pollen record shows a regional vegetation succession of herbs and heathland dominance to Betula, Pinus, Tilia, Ulmus and finally Quercus, which matches the characteristics of the onset of the Eemian interglacial (PAZ LS-E1-E2-E3: cf. Zagwijn, 1961). Towards the top of this interval, at $-22 \mathrm{~m}$ m.s.l. the local vegetation shows a marked peak of Dryopteris and slightly more up-core Nymphaeaceae. Together with an increase in washed-in Pinus and Picea pollen and increase in clay content these changes indicate that aquatic conditions were established. An increase in Corylus and Quercus pollen at $-21.8 \mathrm{~m}$ m.s.l. is indicative of the base of PAZ E4. Washed-in non-pollen marine indicators, such as dinoflagellates, appear onward from this level as well, but fresh water species are dominant. The aggradational fresh water floodplain environment developed in response to sea-level rise immediately downstream (Peeters et al., 2015). It matches the last stages of relative sea-level rise in existing reconstructions for the embayment (Zagwijn, 1983), which based on index-points at the Amersfoort type-locality occurred within PAZ E4.

At a depth of $-19.2 \mathrm{~m}$ m.s.l., a ca. $10 \mathrm{~cm}$ thick fine-grained sandlayer indicates a minor shift towards more organic-rich clayey, but still finely layered floodplain deposits. Marine indicators (dinoflagellate cysts: SI Fig. 1) found from this level upward, indicate an increased in-wash from estuarine areas downstream. At this time, the depositional environment changed from a freshwater to a brackish water river mouth environment marking the transition from transgressive to high-stand situation (Peeters et al., 2015). In agreement with the regional sea-level reconstruction (Zagwijn, 1996, 1983) this transition is correlated with the end of PAZ E4 (Zagwijn, 1996, 1983). The base of PAZ E5 in the Rutten core is placed at $-18.4 \mathrm{~m}$ m.s.l. based on the first occurrence of Carpinus at this level, albeit at low percentages (SI Fig. 1). From this level upward, the wood- and plant-fragment-rich clayey floodplain deposits show a further increase of estuarine in-wash (now also including foraminifera: SI Fig. 1). This correlates to a high-stand in the regional sea-level history, coincident with PAZ E5 (Zagwijn, 1996, 1983).

A thin bed of medium-fine sand at $-15.8 \mathrm{~m}$ m.s.l. marks the onset of regression and the deteriorating climatic conditions at the end of the Eemian. These sands represent small-scale fluvial activity by a local river (not a Rhine channel). The overlying alternation of peats with clays and incorporation of organic-debris up to a depth of $-12.7 \mathrm{~m}$ m.s.l., indicates the persistence a wetland depositional environment. From this level upwards, Pinus and Picea remain the dominant trees. Based on the sedimentology and regional mapping, we regard these tree pollen from this level upward no longer a predominant result of Rhine in-wash. Instead, they would resemble the regional vegetation of the surrounding dry land. Therefore, this level ( -15.8 to $-12.7 \mathrm{~m}$ m.s.l.) is seen as the last stage of the interglacial and correlated to PAZ E6. This matches the sea-level reconstructions for the embayment that show regression from the beginning of PAZ E6 onwards (Zagwijn, 1983, 1996). The regressive contact represents a discontinuity of unknown duration that spans the E5/E6 PAZ boundary. A peak of Betula and Poacea at $-15.0 \mathrm{~m}$ m.s.l. would represent a short (cold) event and/or a local dry phase, within PAZ E6. The occurrence of such events is in agreement with general notion of the regional climate and vegetation developments over the transition of the Eemian to the Early Weichselian in Europe (e.g. Tzedakis, 2003; Sirocko et al., 2005; Helmens, 2014).

A coarse-grained sandy unit is found up to $-9.6 \mathrm{~m}$ m.s.l. This deposit resembles the Weichselian Middle Pleniglacial periglacial Rhine activity (Busschers et al., 2007; Peeters et al., 2015). It truncates the very top of the Eemian interglacial sequence. This contact, which can be regionally traced (Peeters et al., 2015) represents a major hiatus. The pollen assemblage shows much lower percentages of arboreal pollen and a dominance of a wet, herb-rich vegetation generally resembling pollen assemblages encountered in Weichselian Middle Pleniglacial sediments elsewhere in the Netherlands (e.g. Zagwijn, 1974; Van Huissteden et al., 2003). Higher up, the record is completed by local fluvial and aeolian finegrained sandy deposits of Late Pleniglacial - Late Glacial age (Peeters et al., 2015), often showing cryoturbated sedimentary structures (Fig. 3). From a depth of $-5.2 \mathrm{~m}$ m.s.l. up to the surface, Holocene lagoonal and fluvio-deltaic deposits cap the sequence.

\subsection{Luminescence dating}

The derived luminescence-ages are in stratigraphical order within their uncertainties (Table 1). The two samples associated with Eemian pollen-zones (PAZ E4 and E6) return ages of $109 \pm 6 \mathrm{ka}$ and $112 \pm 11 \mathrm{ka}$ (depths $-19.17 \mathrm{~m}$ and $-15.12 \mathrm{~m}$ m.s.l. respectively). The sand layer at a depth of $-12.52 \mathrm{~m}$ m.s.l. gives an age of $43 \pm 3 \mathrm{ka}$, in agreement with the pollen association (PAZ: W) and the regional geological mapping of the Pleniglacial erosive phase (see above). The sample associated with the top of the Late Saalian paleovalley (PAZ: LS) provides an age of $161 \pm 14 \mathrm{ka}$ (depth $-24.03 \mathrm{~m}$ m.s.l.), whereas the deeper sample $(-25.17 \mathrm{~m}$ m.s.l.) returned $421 \pm 29 \mathrm{ka}$. This last age estimate should be interpreted with caution because it is beyond the reliable part of the dose response curve. However, it is clear that the sampled deposit is much older than the overlying sediments. The local presence of 'old' sand in the deglacial paleovalley, possibly transported over short distances and under partial ice-cover, may also have affected the result of the sample ( $161 \pm 14 \mathrm{ka}$, see Fig. 3$)$ : it is likely that it contains material that was incorporated from the old underlying deposit, but as poor bleaching cannot be detected in this age range this inference remains speculative.

\subsection{Paleomagnetism}

The magnetic polarity is based on quality 1 and 2 ChRM directions only, of which examples are given in Fig. 2. All ChRM directions are provided in Tables I and II in the SI. Fig. 2 shows examples of Zijderveld diagrams of AF demagnetized samples of quality 1, 2 and 3 (Fig. 2A to F). Both standard and per component diagrams are shown for each AF example. Also, examples of Zijderveld diagrams of quality 1 and $2 \mathrm{TH}$ samples are given (Fig. 2G and $\mathrm{H}$ ). From the SI Tables I and II and Fig. 3 it becomes apparent that almost all samples have ChRM directions with a positive inclination; only two of the ChRMs have negative inclination, one with a northern declination, the other with a southern declination. TH demagnetized samples have more samples with a shallow inclination, some of them can be labelled excursional even with a normal declination (SI Tables I and II). All samples that show ChRM directions with deviations of over $40^{\circ}$ from the normal virtual geomagnetic pole of the Brunhes (Merril and McFadden, 1994) have been labelled excursional (SI Tables I and II). 
Table 1

Results of feldspar pIRIR 290 dating.

\begin{tabular}{|c|c|c|c|c|c|}
\hline NCL labcode & Sample depth (m below m.s.l.) & Equivalent dose (Gy) & Dose rate $(\mathrm{Gy} / \mathrm{ka})$ & Age (ka) & Validity \\
\hline NCL-6312180 & 12.5 & $76 \pm 3$ & $1.76 \pm 0.09$ & $43 \pm 3$ & Likely OK \\
\hline NCL-6312181 & 15.1 & $265 \pm 22$ & $2.38 \pm 0.1$ & $112 \pm 11$ & Likely OK \\
\hline NCL-6312182 & 19.2 & $231 \pm 9$ & $2.11 \pm 0.1$ & $109 \pm 6$ & Likely OK \\
\hline NCL-6312183 & 24 & $211 \pm 12$ & $1.31 \pm 0.08$ & $161 \pm 14$ & Likely OK \\
\hline NCL-6312184 & 25.2 & $700 \pm 32$ & $1.66 \pm 0.09$ & $421 \pm 29$ & Questionable \\
\hline
\end{tabular}

There appears to be no correlation between the paleomagnetic direction and sampling in either fine-grained lithology (silts and clays) or sandy sediment. However, rotation of the more sandy sediment within the core liner cannot always be excluded. Plotted against their stratigraphic depth, the ChRM directions show two different zones, a zone with normal polarity from the surface down to a depth of $-12.08 \mathrm{~m}$ below m.s.l., and a zone with "mixed" directions from $-12.08 \mathrm{~m}$ down to the base of the core at $-28.62 \mathrm{~m}$ (Fig. 3). Within core-segments from the "mixed" zone, both normal and excursional directions are found, often centimeters apart. Where multiple paleomagnetic samples were obtained from the same core segment, cross-checks on possible rotational disturbances were carried out and confirmed the excursional directions. Only for the quality 1 excursional sample at $-12.35 \mathrm{~m}$ m.s.l. - just above the top of the Eemian sequence at $-12.6 \mathrm{~m}$ - performing such a check was not possible, due to the low number of samples from this core segment.

\subsection{Rock magnetism}

To constrain the interpretation of the ChRM directions, rockmagnetic measurements have been carried out. The majority of the samples had the NRM decayed at temperatures below $360{ }^{\circ} \mathrm{C}$ indicating a dominant contribution of iron sulphides to the NRM (see Fig. 4 for some examples). Rock-magnetic measurements can help distinguishing between biogenic and diagenetic iron sulphides and thus primary versus delayed NRM acquisition (e.g. Vasiliev et al., 2008). Biogenic minerals are formed in situ often at the oxic-anoxic interface in sedimentary settings (Bazylinski and Frankel, 2004) while diagenetic sulphides are either formed shortly after sedimentation by early diagenetic processes (often bacterially mediated) or later in time by remagnetization (e.g. Roberts and Weaver, 2005; Rowan and Roberts, 2006).

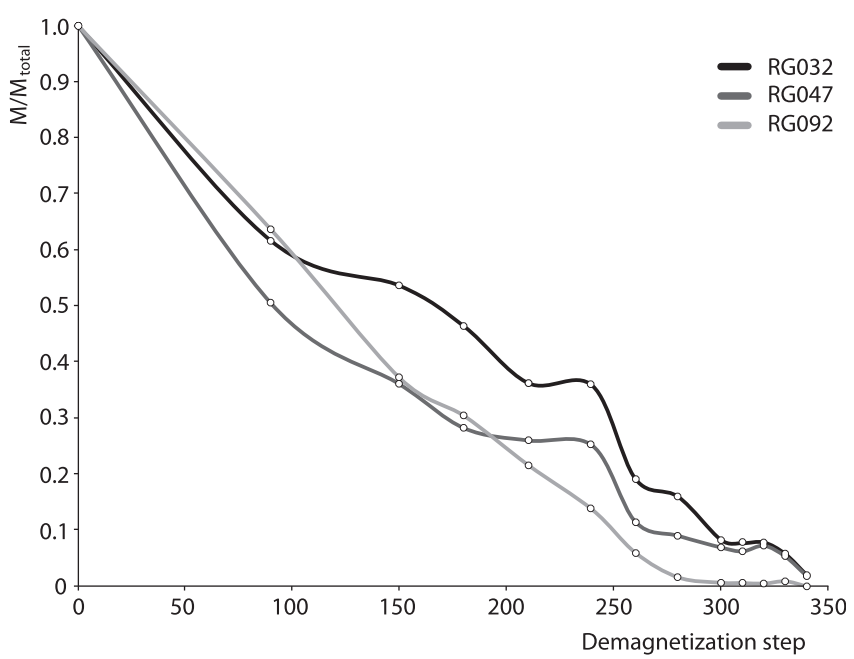

Fig. 4. Normalized decay curve of three TH demagnetized quality 1 samples. Demagnetization steps are in ${ }^{\circ} \mathrm{C}$.
A wide range of hysteresis properties was observed for the studied samples. Fig. 4 shows a representative selection of quality 2 and quality 3 samples. These quality labels were selected in order to distinguish GRM affected from non-GRM affected samples. No samples of quality 1 were selected because no GRM was present in these samples. Typical hysteresis loops and high-resolution FORC diagrams with single domain (SD) behaviour are shown in Fig. 5. These hysteresis loops are relatively squared (Tauxe et al., 1996) with $\mathrm{M}_{\mathrm{rs}} / \mathrm{M}_{\mathrm{s}}$ ratios of $\sim 0.4-0.5$ and $\mathrm{B}_{\mathrm{c}}$ values of $\sim 20-40 \mathrm{mT}$ (Fig. $5 \mathrm{a}$ ). High-resolution FORC measurements indicate a range of magnetic properties with variable coercivity distributions and levels of magnetostatic interaction (Fig. 5b). Some FORC diagrams have a central ridge along the $B_{c}$ axis with negligible vertical spread, which indicate a lack of magnetostatic interactions (Pike et al., 1999). This FORC central-ridge signature corresponds to that of non-interacting or weakly interacting SD particles, which probably indicates the presence of significant amounts of biogenic magnetic minerals produced by magnetotactic bacteria (Egli et al., 2010). The FORC diagrams also have another component consisting of concentric contours with a relatively large vertical spread, which indicate strong magnetostatic interactions (Pike et al., 1999; Roberts et al., 2000). This FORC component also has two other pronounced features. First, the centre of the concentric contours is shifted downward to negative $B_{i}$ values. Second, there is a negative peak close to the $B_{i}$ axis in the lower quadrant (white area in Fig. 5b). These signatures all indicate a strongly interacting SD magnetic particle assemblage (Newell, 2005; Pike et al., 1999; Roberts et al., 2000). This type of FORC distributions is typical of diagenetic SD greigitebearing sediments (e.g. Roberts et al., 2011, 2006, 2000; Rowan and Roberts, 2006; Sagnotti et al., 2010; Vasiliev et al., 2007). Many FORC diagrams have a variable mixture of these two FORC distributions: the central ridge representing one end member and the vertically spread concentric contours the other (Fig. 5b). These samples, therefore, contain a mixture of non-interacting and interacting SD particles. With the non-interacting SD particles having a biogenic origin (Egli et al., 2010; Chang et al., 2014a, 2014b). Both types of magnetic minerals are present throughout the stratigraphic column; they are not restricted to a specific zone of magnetic polarity.

CLG IRM component analysis shows the presence of three components, a low-, a high-coercivity component and, at very low coercivities, an extra component that is required to fit the slightly skewed-to-the-left coercivity distribution. This extra component is an artefact of the fitting method and not given a physical meaning (Egli, 2004; Heslop et al., 2004). The artefact component (component 1, Fig. 6D, with 6A, B and C for correlation to Fig. 3) has a mean dispersion parameter (DP) value of $0.281(\log \mathrm{mT})$ and a mean acquisition field $B_{1 / 2}$ of $25.23 \mathrm{mT}$. The low-coercivity component 2 has a mean DP of $0.197(\log \mathrm{mT})$ and a mean $\mathrm{B}_{1 / 2}$ of $67.48 \mathrm{mT}$, with a range between 48 and $91 \mathrm{mT}$ (Fig. 6D and E). Component 3 has a high-coercivity with mean DP of 0.318 and $\mathrm{B}_{1 / 2}$ of $\sim 260 \mathrm{mT}$, with a range between 158 and $794 \mathrm{mT}$. This latter component contributes on average 6 per cent to the remanence (one clearly deviating sample has a 22 per cent contribution). Component 3 most likely is hematite but was not further investigated because its contribution 

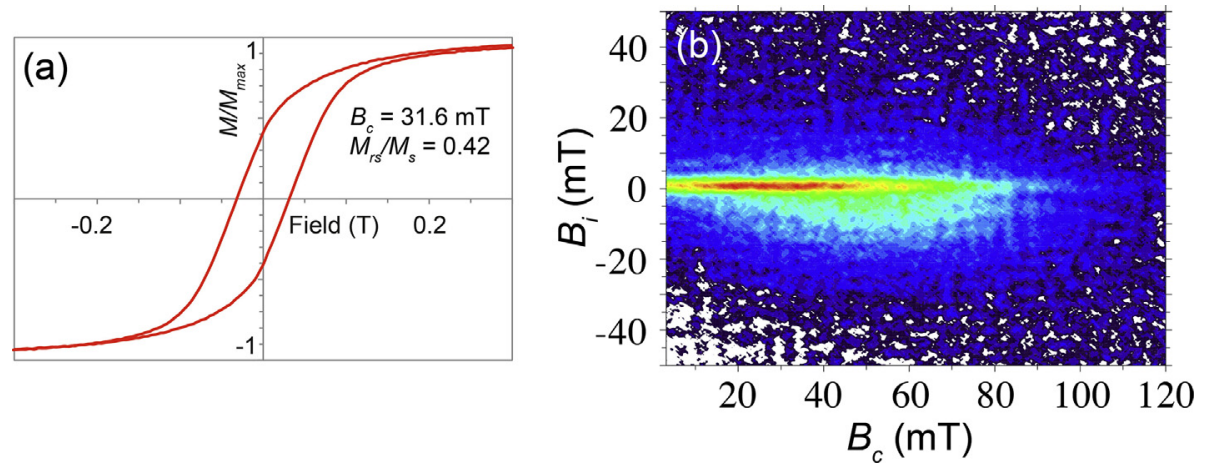

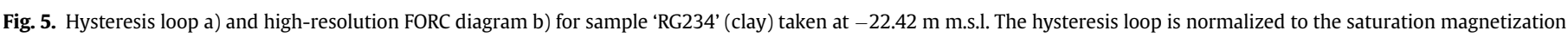

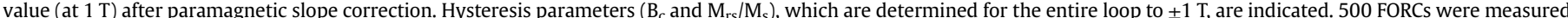

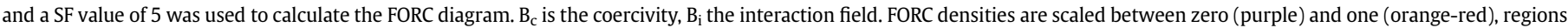

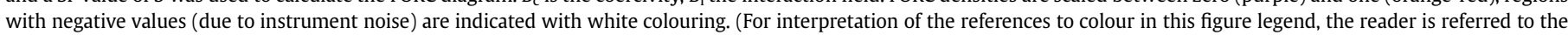
web version of this article.)

to the NRM is marginal if present at all. Component 2 is greigite, as also deduced from the hysteresis and FORC measurements. It was already suspected to be present after AF demagnetization of the NRM: a considerable portion of the samples showed an increase of intensity after demagnetization at high AF levels. Even though samples with high GRM were not used for interpretation of ChRM directions, all samples were used for IRM analyses. No differences can be identified in the IRM intensities between the different quality samples (Fig. 6D and SI Table II).

The magnetic susceptibility (with a range of $0.19 \times 10^{-8} \mathrm{~m}^{3} / \mathrm{kg}$ to $446 \times 10^{-8} \mathrm{~m}^{3} / \mathrm{kg}$ ) and the NRM intensity show a clear one-toone relationship with each other (Fig. $6 \mathrm{~F}$ and $\mathrm{G}$ ) but not with the magnetic polarity (Fig. 6A). Samples from core B15F1501 show a wide range of NRM intensities from $2.76 \times 10^{-4} \mathrm{~A} / \mathrm{m}$ to over no less than $4.5 \times 10^{-1} \mathrm{~A} / \mathrm{m}$. A zone with increased intensities is observed from -18.10 to $-24.56 \mathrm{~m}$ m.s.l. (Fig. $6 \mathrm{G}$ ).

\section{Discussion}

\subsection{Paleomagnetic signal in the Rutten core and Blake Event boundaries}

The sedimentary context, pIRIR luminescence dates and the characteristic Eemian pollen record together identify the paleomagnetic excursional zone, between $-22.8 \mathrm{~m}$ and $-12.6 \mathrm{~m}$ m.s.l. in core B15F1501, as the Blake Event. Here, the syn-depositional nature of the recording of the Blake Event at Rutten (Fig. 3) is discussed. The deposition took place in a quiet floodbasin sedimentary environment, implying synchronous acquisition of pollen and paleomagnetic signals, with none or very little delayed NRM acquisition. The rock-magnetic results show AF quality 2 samples, in which the GRM was corrected for by the per component protocol, to be mainly composed of biogenic magnetic minerals (Fig. 5) which form at the oxic-anoxic interface in aquatic habitats (Bazylinski and Frankel, 2004). This means that the paleomagnetic signal is partly in-situ biogenic recorded, which implies nondelayed acquisition.

Recording of the Blake Event begins below the base of PAZ E1 (as in the earlier study at NN2, Sier et al., 2011) and continues all the way up to the PAZ E6 truncation contact with the Weichselian Pleniglacial. The lowermost AF quality 2 sample with biogenic minerals is sample RG220 with a depth of $-22.48 \mathrm{~m}$ m.s.l. in PAZ E1, and several AF and TH quality 1 samples were measured from levels just below PAZ E1. This indicates an onset of the Blake Event just before the beginning of the Eemian. Below $-22.8 \mathrm{~m}$ m.s.l., the Blake Event appears also recorded. Sedimentological study of the sequence, however, identifies at that depth a possible paleosol in the top of the fluvial deposits, besides considerable postsedimentary ferric precipitation in these permeable beds as it became sealed by the fine-grained transgressive units above. Because of the ferric precipitation, the paleomagnetic directions from the interval between $-25.0 \mathrm{~m}$ and $-22.8 \mathrm{~m}$ m.s.l. are regarded as post-depositional overprints (cf. Fig. 3).

Above $-12.6 \mathrm{~m}$ m.s.l, two measurements from within Weichselian Pleniglacial deposits (luminescence dated to $43 \pm 3 \mathrm{ka}$ ) give excursional ChRM directions. At this position, excursional directions cannot be linked to the Blake Event. For this sample, it cannot be excluded that the core-liner was accidently rotated during retrieval (see Section 4.3). If the core orientation is correct, it is possible to attribute the signal to the much younger Laschamp paleomagnetic excursion. It would be a coincidence if that event turns out superimposed on the Blake Event at Rutten.

\subsection{Duration of the Blake Event and the Eemian in NW Europe}

The results from the Rutten core show the duration of the Blake Event to be of roughly the same duration as the Eemian interglacial in NW Europe. Recording of the Blake Event commences just before the onset of PAZ E1 and continues throughout the preserved parts of PAZ E6. These results at Rutten reproduce the earlier findings at site NN2 (Sier et al., 2011), albeit that the upper boundary of registration of the Blake Event at Rutten within PAZ E6 (cf. Zagwijn, 1961; equivalent to PAZ EVI of Menke and Tynni, 1984) is considerably later than what had been deduced at NN2 (terminating in PAZ EIVb3 cf. Menke and Tynni, 1984; Sier et al., 2011; equivalent to the later part of PAZ E4 cf. Zagwijn, 1961).

Independent estimates for both the duration of the Eemian and for the duration of the Blake Event exist from other studies, to which the new results can be compared. The duration of the Eemian in NW Europe has been estimated by Müller (1974) and Hahne et al. (1994) to be ca. 11,000 years from partially varved deposits at Bispingen and Quakenbrück (Fig. 1). It should be noted that actual counted varves only make up ca. 7000 years (PAZ transition LS/E1 and to E5/E6) of the ca. 11,000 year duration (Müller, 1974; Hahne et al., 1994; Caspers et al., 2002). The additional 4000 years come from extrapolation of inferred sedimentation rates in the slightly varying, micro-laminated, lithology in PAZ E6 (Müller, 1974). In the ELSA record in the German Eifel (Sirocko et al., 2005), the time interval between the E5/E6 boundary (their LEAP event, the top of their "Eem s.s.") and the beginning of NorthAtlantic cold stage 24 is ca. 7700 varve years, which provides a theoretical maximum duration of PAZ E6. 


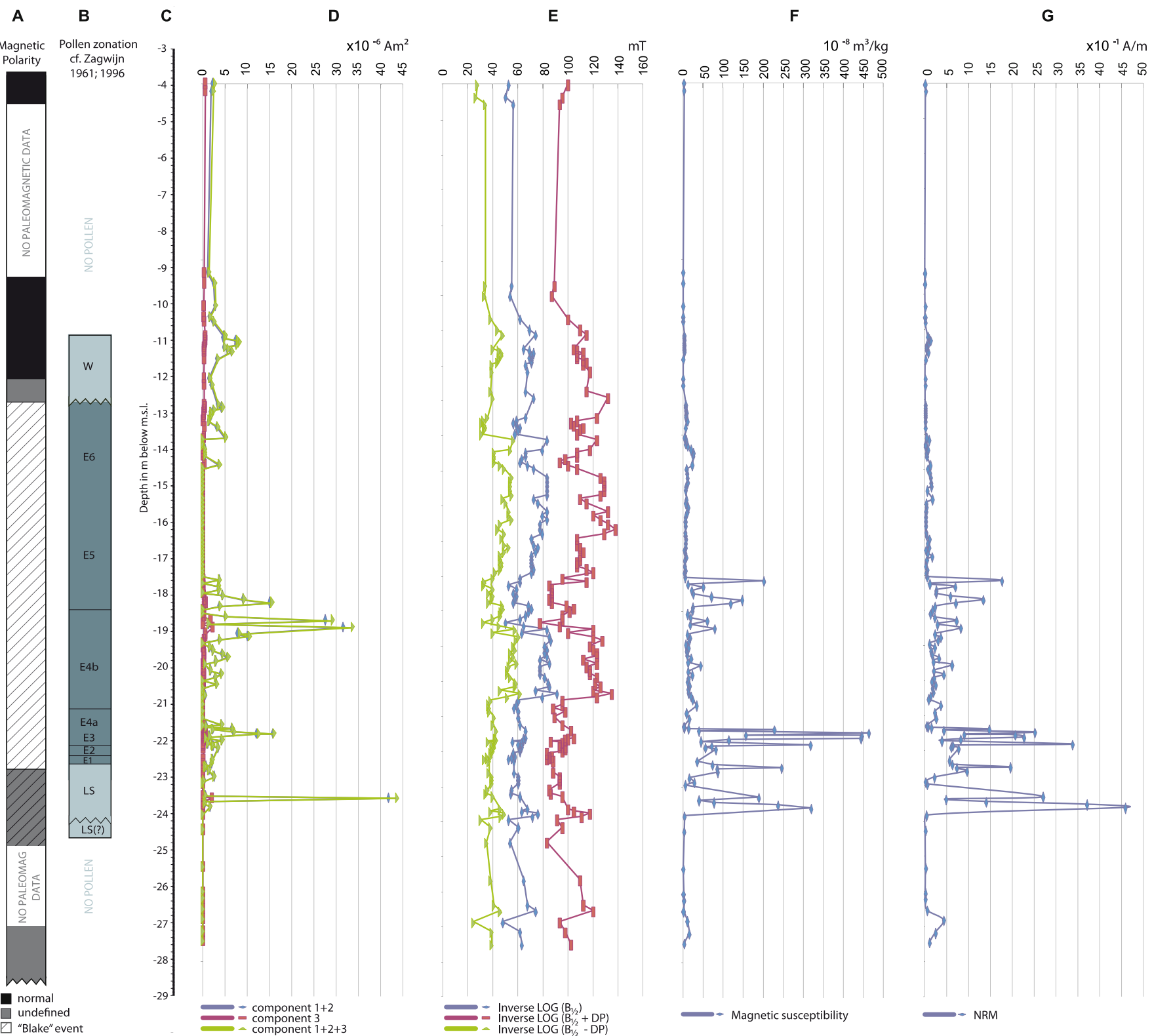

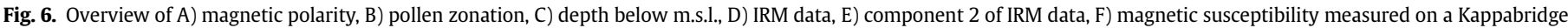
KLY2 and G) NRM intensity from core B15F1501 plotted versus stratigraphic depth.

In the Rutten core, not the full length of PAZ E6 and hence not the full length of the Eemian is recorded, but how much time within PAZ E6 is missing is unknown. For that reason, a minimum duration of ca. 8000 years and a maximum of ca. 11,000 years are assigned to the interval spanning PAZ E1 to the truncated top of PAZ E6 at Rutten. Comparison of the duration of the Blake Event to the durations of the Eemian at Rutten and Bispingen, should include the possibility that the Blake Event terminated before PAZ E6 ended (at Rutten the top of PAZ E6 is an erosional contact, at Bispingen and in ELSA it is not). More paleomagnetic research at new sites (including at Bispingen and in the Eifel) is needed to properly determine the position of the top of the Blake Event in the upper Eemian. The duration estimate for the Blake Event should further include for a few hundreds of years of time within the Blake Event just before the onset of PAZ E1; at Rutten represented by the

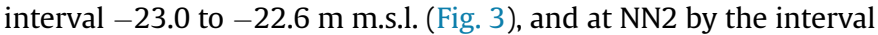
6.90-7.70 m below surface (Sier et al., 2011; estimated 200-300 years). Still, the 8000 and 11,000 years estimates for the length of Eemian record at Rutten copy as minimum and maximum estimates for the length of the Blake Event. Note that in southern Europe, last-interglacial sequences have a considerably longer duration, for example $17,700 \pm 200$ years in Southern Italy (Brauer et al., 2007).

Importantly, the above duration estimates for the NW European Eemian and the Blake Event come from varve counting and extrapolation of sedimentation rates of partially varved sequences, and are independent of numeric dating and/or precession tuning. This is unlike most other estimates for the Blake Event duration in for example the marine cores discussed below.

\subsection{Comparison with other Blake Event records in Europe}

In this study, the identification of sampled paleomagnetic signals as excursional is based on deviating declinations and very 
shallow inclinations (SI Tables I and II). In an unorientated core, 'Rutten'-style samples would be difficult to identify as being excursional. Only one sample in the Rutten core has a negative inclination for its ChRM direction in the zone that is interpreted as the Blake Event (Fig. 3, and SI Tables I and II). Also, the ChRM directions of NN2 and Caours (Somme valley, France) were more prominent excursional in declination than in inclination (Sier et al., 2011: 2015). Although sedimentary recording issues can never be fully excluded to have influenced the recording of the paleomagnetic signal, it is possible that the lack of negative inclinations in north-western and central Europe is a geographical expression of the Blake Event. Excursional declinations with positive inclinations seem to dominate the paleomagnetic directions. In other regions across the globe, the Blake Event is identified by its clear negative inclinations (e.g. Bourne et al., 2012; Smith and Foster, 1969).

Some clear similarities and differences can be noted when comparing the Rutten to the NN2 record. In NN2 the lower boundary of the Blake Event is well defined on the basis of highquality paleomagnetic directions above and below it. Like the Rutten site, the NN2 site has a detailed rock-magnetic record. The NN2 Blake Event is registered by magnetite with a varying amount of hematite. Combined with the sedimentary indications for a high sedimentation rate delayed NRM acquisition is not very likely. Also, the rock-magnetic properties follow closely the local environmental changes suggesting again, an in situ signal (Sier and Dekkers, 2013). Both sites have good pollen preservation and show a rather complete PAZ sequence (Sier et al., 2011; this study). The NN2 pollen record, however, is more condensed from pollen zone IVb3 onward (cf. Menke and Tynni, 1984; PAZ E4b cf. Zagwijn, 1961). This is due to a decrease in sedimentation rate as a result of a dry phase in and around the Neumark basin, to which small basins are sensitive (Sier et al., 2011; Bakels, 2012). The Rutten site was not, or less hydrologically sensitive to such dry phases because of its position in the lower Rhine delta. The upper boundary of the Blake Event at NN2 was arbitrarily defined on the uppermost undisputed high-quality excursional direction sample. With low-quality samples with potential excursional directions in younger levels excluded, the minimum duration of the Blake Event in NN2 is around 3400 years (Sier et al., 2011). The Rutten site records the Blake Event at higher quality over a longer duration (see above).

Other studies have reported paleomagnetic events in lastinterglacial deposits in NW, central and NE Europe before. A study of an unorientated core from Anholt, Denmark in shallow marine Saalian and Eemian sediments showed two consecutive paleomagnetic samples with negative inclinations, interpreted as the Blake Event (Abrahamsen, 1995). In the same study, two further isolated samples with negative inclinations between samples of normal directions, were not considered as the Blake Event. The full range over which negative inclinated samples are found in the Anholt core, closely matches the range and duration of the Blake Event in the Rutten core, and the positioning of the event with respect to pollen zonations matches that in Rutten and NN2.

A recent study in Wels-Aschet (Austria) identified the Blake Event in a loess sequence in central Europe (Scholger and Terhorst, 2013). This identification was based on virtual geomagnetic pole (VGP) latitude values of around $-10^{\circ}$ to $5^{\circ}$. These VGP values are clearly not corresponding to fully reversed orientations, similar to the results presented in this study.

A recent multidisciplinary study of the Netiesos section (southern Lithuania) identified the Blake Event in combination with the "Eemian" (Mikulinian) pollen zonation in NE Europe (Baltrūnas et al., 2013). The authors interpret three consecutive fully reversed ChRM directions as the Blake Event. However, throughout the Netiesos section, ChRM directions with a south declination and positive inclination are reported (Baltrūnas et al., 2013), that should also be interpreted as excursional following the definitions of Merril and McFadden (1994) as deployed on the Rutten and NN2 sites. It thus seems that the Blake Event of the Netiesos section in NE Europe spans the full Mikulinian, similar to the new results for the Eemian in NW Europe and those for central Europe.

\subsection{Correlation of the Rutten Blake Event with the MIS record and Southern Europe}

The previous paragraphs suggest that the Blake Event and the Eemian have commenced rather synchronously in NW Europe and central Europe, with the Blake Event starting just before PAZ E1 in Rutten and NN2 as the example sites. Multiple records exist of the Blake Event within marine cores that also have $\delta^{18} \mathrm{O}$ records, which allows to tie terrestrial records that registered the Blake Event to marine isotope signals and its standard stage divisions (MIS 6, Termination II, MIS 5e; Fig. 7).

In the Eastern Mediterranean, the Blake Event is registered immediately above sapropel S5 but is of apparent short duration at these locations (Tric et al., 1991; Tucholka et al., 1987). In the western Mediterranean, where this sapropel does not occur, the Blake Event is registered with apparent longer duration (Tucholka et al., 1987). This is of importance because datings of sapropel S5 are used to anchor the MIS curve and the onset of the Blake Event on an absolute time scale (see also the SI of Sier et al., 2011). The start of MIS 5e (midpoint of Termination II) at ca. 131 ka coincides roughly with the base of sapropel S5 at $129.5 \mathrm{ka}$ (Ziegler et al., 2010; precession-tuned to U/Th dates in the Sanbao and Hulu caves in China). MIS 5e reaches maximum depleted $\delta^{18} \mathrm{O}$ values within sapropel S5. A plateau value is reached around $126 \mathrm{ka}$, which starts to drop off near the top of sapropel S5, dated at $121.5 \mathrm{ka}$ (Ziegler et al., 2010). If indeed the Blake Event postdates sapropel S5, the Eemian in NW Europe would start at this moment.

Independent age estimates for the Blake Event are available from a number of studies and they generally indicate a younger age than that of sapropel S5. In a stalagmite in northern Spain (Osete et al., 2012), the Blake Event is U/Th-dated and spans the interval from $119.3 \pm 0.8$ to $112.0 \pm 1.9 \mathrm{ka}$ (including their B3 part of the event) and postdates the isotope signal peak correlated to MIS 5e. In the earlier mentioned Netiesos site in southern Lithuania (Baltrūnas et al., 2013), dating of the base of the Blake Event comes from ESR dating of freshwater molluscs at $112.5 \pm 10.8$ and $112.1 \pm 25.9 \mathrm{ka}$ (Gaigalas and Molodkov, 2002), whereas the top of sequence produced $\mathrm{U} / \mathrm{Th}$ dates of $108.8 \pm 8.7$ and $105.7 \pm 10.0 \mathrm{ka}$ (Gaigalas et al., 2005). The earlier mentioned Caours tufa-sequence produced a set of U/Th (TIMS) of ca. $120 \mathrm{ka}$ (Antoine et al., 2006) that relate to the base of the Blake Event $(123 \pm 3 \mathrm{ka}$; Sier et al., 2015). In the Rutten core (this paper), the luminescence dates of $109 \pm 6$ and $112 \pm 11 \mathrm{ka}$ are from within the Blake Event.

An independent age constraint for the E5/E6 boundary comes from the ELSA-record in NW Germany (Sirocko et al., 2005). In that record, this boundary times 7700 years before the onset of a dust event that correlates to North Atlantic cold event C24 and to stadial GS-25 in the Greenland ice records (e.g. Sirocko et al., 2005; Rasmussen et al., 2014). The age of this onset according to the NGRIP (North Greenland Ice-core Project) age-model is $111 \mathrm{ka}$ (NGRIP members 2004) and in the NEEM (North Greenland Eemian Ice Drilling) age-model is 108.5 ka (NEEM community Members, 2013; their SI Fig. S7). This gives an age of E5/E6 boundary of 118.7 respectively $116.2 \mathrm{ka}$ in the ELSA record. Assuming that this cooling-driven regional vegetation development was nearsynchronous throughout NW Europe, this provides an age point in the upper part of the Blake Event. 


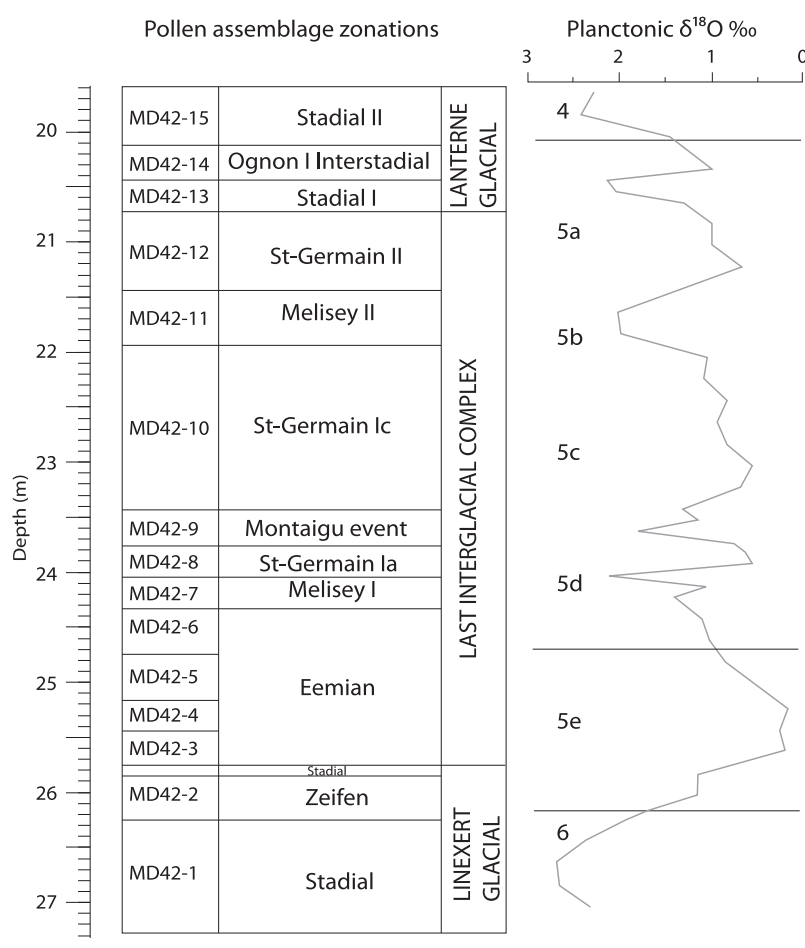

Sánchez-Goñi et al. (1999); Shackleton et al. (2003)
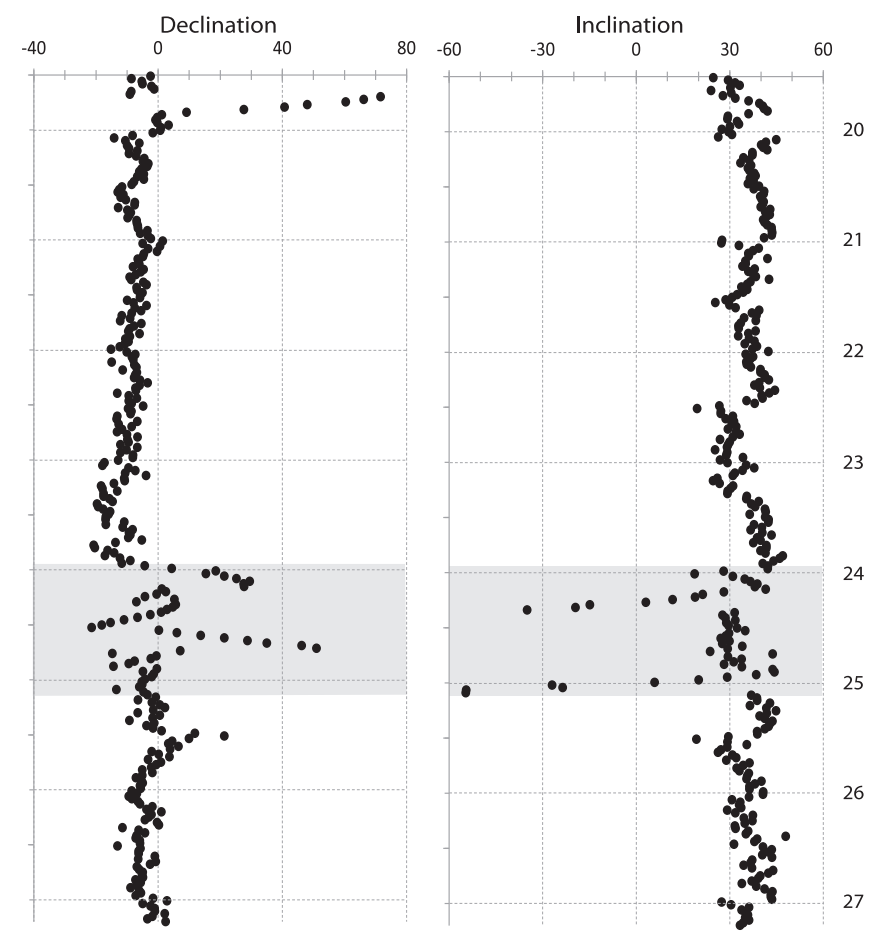

Thouveny (2004); Thouveny et al. (2004)

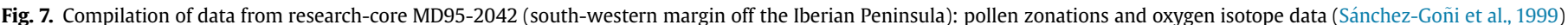
and paleomagnetic record including the Blake (Thouveny et al., 2004). Paleomagnetic data retrieved from http://www.pangaea.de (Thouveny, 2004).

Further literature review on the Blake Event in marine settings shows nearly all sites to yield data supporting an onset after the MIS 5e peak, regardless of large differences in apparent duration of the event. On the Yemak plateau (northern Atlantic Ocean), the Blake Event starts well after the onset of MIS 5e and its inferred duration is ca. $10 \mathrm{kyr}$ (Nowaczyk et al., 1994). The same applies to marine core A179-4 (Blake-Bahama Outer Ridge), with an estimated duration of the Blake Event of $7 \mathrm{kyr}$ (Smith and Foster, 1969; Wollin et al., 1971) and the ODP site 1062 cores where the Blake Event starts slightly after MIS 5e with an estimated duration of the event of $6.5 \pm 1.3 \mathrm{kyr}$ (Bourne et al., 2012). The Blake Event at the Bermuda Rise has a notably short estimated duration of $<1000$ years and straddles the MIS 5d-5e boundary (Channell et al., 2012). An exception on the post-MIS 5e plateau position for the Blake Event comes from the study of core MD972151 in the South China Sea, where the Blake Event was identified well before the MIS 5e plateau (Lee et al., 1999; Lee, 1999). The quality of the data seems to be good but this claimed position of the Blake Event is about $11 \mathrm{kyr}$ at odds with all other studies.

An important reference site is core MD95-2042 off the coast of Portugal, for which marine isotope stratigraphy and pollen biostratigraphy exists (Sánchez-Goñi et al., 1999; Shackleton et al., 2002). An interglacial pollen signal commences shortly after the beginning of MIS 5e, on the rising limb towards the benthic $\delta^{18} \mathrm{O}$ plateau, and climax vegetation culminates in the plateau-interval. Paleomagnetic data of core MD95-2042 also exists (Thouveny et al., 2004). The $\delta^{18} \mathrm{O}$, pollen zonation, and paleomagnetic data combined are shown in Fig. 7. Thouveny et al. (2004) highlight that the full Blake Event at site MD95-2042 features two inclination anomalies, at 122 and 115 ka respectively. The Blake Event again begins well after the MIS 5e plateau is reached (Fig. 7). It coincides with pollen assemblage zones that mark climax stages of the interglacial vegetation succession.

The duration of the pollen-defined "Eemian" off SW Europe in
MD95-2042 is 16,400 years (126.1-109.7 ka; age-model published in Shackleton et al., 2002), which matches the varved-based duration estimate from southern Italy (Brauer et al., 2007). The inferred duration for the MD95-2042 Blake Event matches that of the Rutten site. It is the pollen signal of the onset of the biostratigraphical Eemian that is diachronic between the SW European MD95-2042 site and the NW European Rutten and NN2 sites. It may be that the pollen-defined stages of ending of the interglacial conditions in NW and SW Europe (e.g. developments recorded over the PAZ E5/E6 boundary), are less diachronic than those at the onset of temperate forest development. The last pollen zone of the Eemian appears to extend into MIS 5d, in NW Europe in a similar way (this study) as earlier recognized off Iberia (Shackleton et al., 2003; Tzedakis, 2003) and in ELSA (Sirocko et al., 2005). Based on the recording of the Blake Event in MD95-2042 (Fig. 7), the beginning of the Eemian in NW Europe (PAZ E1) lags that of the "Eemian" of Southern Europe by ca. 5 kyr. In NW Europe, interglacial vegetation begins to establish ca. $10 \mathrm{kyr}$ after MIS 5e began, whereas in SW Europe the lag is ca. $4.5 \mathrm{kyr}$ (Fig. 8).

\subsection{Implications for paleoenvironmental and archeological research}

Identifying noteworthy diachroneity in the onset of interglacial conditions between southern and northern parts of Atlantic Europe, implies that vegetational and climatic developments during the Late Saalian and Eemian were very different from those during the Late Glacial to Holocene. Whereas in SW Europe development of climatic warming and vegetation change during Termination I and Termination II may still be considered essentially analogous, NW Europe would have seen a (very) late return to temperate climate conditions in the Last Interglacial, some 5000 years 'too late', meaning non-analogy with the beginning of the Holocene. Yet, when the interglacial vegetation also established up 


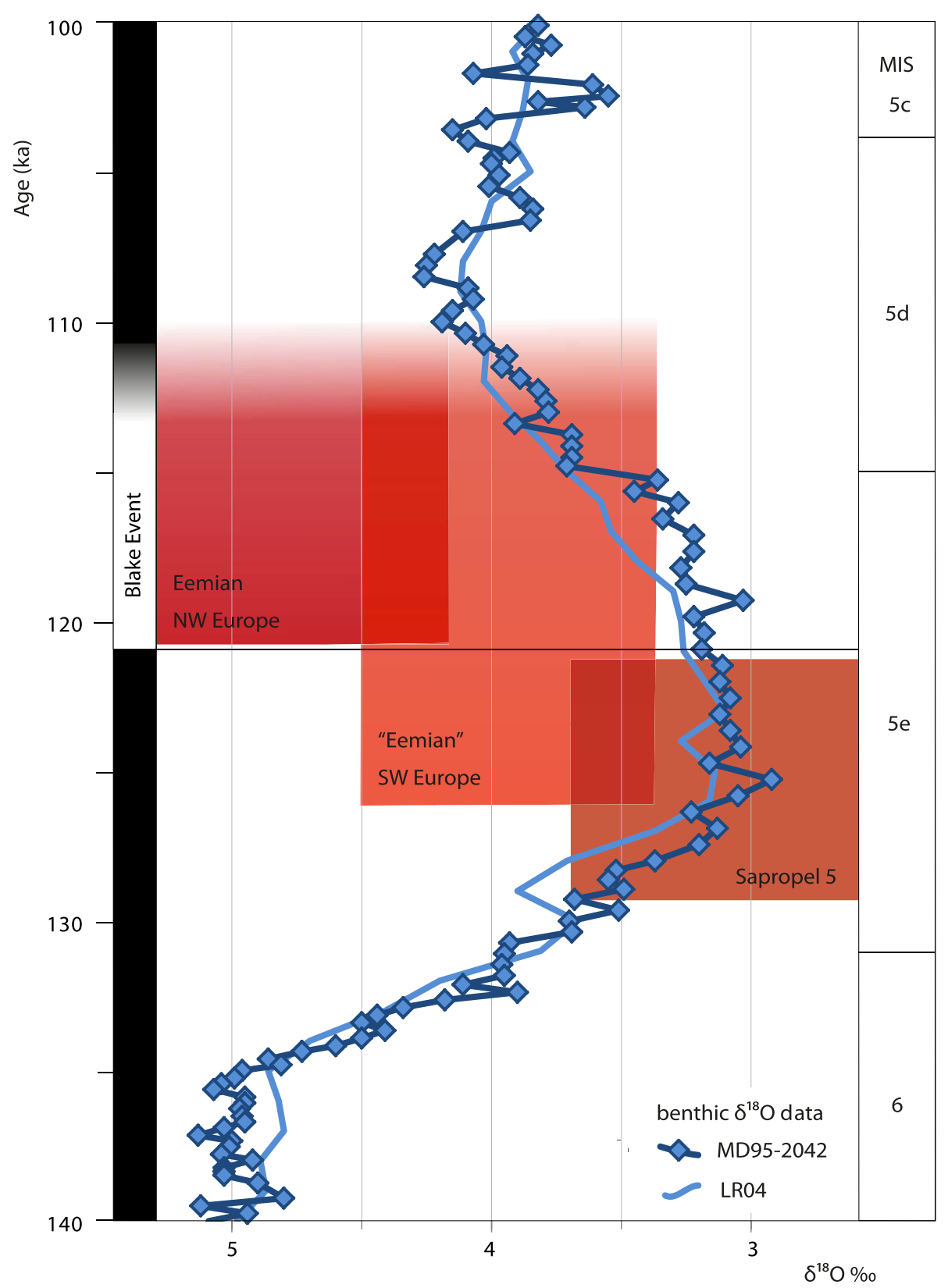

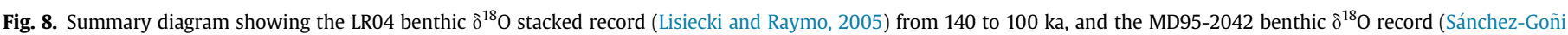

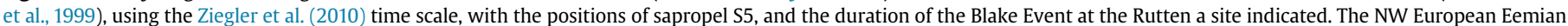

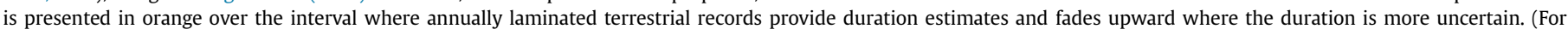
interpretation of the references to colour in this figure legend, the reader is referred to the web version of this article.)

north, this pioneer-vegetation transition went rapidly: essentially equally rapid as in the Holocene, unaffected by the relatively later timing. It suggests that regional climatic conditions over Europe and the North Atlantic in the first part of MIS 5e were very different from those in equivalent parts of MIS 2 and 1 (Late Glacial and Early Holocene). Known differences between the melting history of the Greenland ice cap following Termination II (NEEM community Members, 2013) and following Termination I (Lowe et al., 2008), also seen in North Atlantic paleoceanography (Bauch et al., 2000), can be regarded to provide mechanisms that can explain the difference in climate history between the Eemian and Holocene (Renssen et al., 2012; Cohen et al., 2014).

Past interglacial histories may not be analogous to that during the Late Glacial and Holocene, which brings potential pitfalls in their interpretation with it. These can only be identified and circumvented by applying multiple independent paleoenvironmental reconstruction and dating techniques on data collections comprising both marine and terrestrial sites. Paleomagnetic identification of the Blake Event from inclination and declination measurements shows to be a crucial technique to resolve these differences for the Last Interglacial.

A global stratigraphic section and point (GSSP) for the base of the Late Pleistocene and the Last Interglacial is still on the agenda to be defined (Head et al., 2013) and the community is discussing potential sites. This paper stresses the importance of paleomagnetics in assessing diachroneity between potential GSSP locations, and the outcomes suggest far-field (in glacio-isostatic adjustment geophysical context) Last-Interglacial sites away from Atlantic 
Europe to be better candidate GSSP host-regions than the classic Eemian type area in NW Europe.

One of the reasons to perform paleomagnetic investigations of the Blake Event was to improve application in the dating of potential Last-Interglacial archaeological sites. For NW and central Europe, the long duration of the Blake Event implies in an archaeological context in absence of pollen data a confirmation of the Eemian as interglacial age. However, within the Eemian no additional resolution is possible.

\section{Conclusions}

In this study, a detailed analysis was performed on a 25-m long orientated core taken at Rutten (The Netherlands), close to the stratotype localities for the Eemian in the Netherlands. The position of the onset of the Blake Event within the Eemian pollen biostratigraphy for NW Europe is confirmed, the duration of the Blake Event better constrained, and diachroneity in the onset of the interglacial conditions across Europe assessed. The latter complicates correlation to the marine isotope stratigraphy and results in differences of that correlation for the Eemian of NW Europe and the "Eemian" of SW Europe.

Regarding the onset of the NW European Eemian, the new data from Rutten confirmed results and hypotheses from the earlier studied Neumark Nord 2 site (Sier et al., 2011). The identification of the Blake Event at these two sites, and correlation to findings in marine core MD95-2042 (Sánchez-Goñi et al., 1999; Thouveny et al., 2004) indicates NW and central Europe to be ca. 5000 years later in entering interglacial environmental conditions than southern Europe.

The Rutten site provides evidence for an unanticipated long duration of the Blake Event, with a minimum duration of ca. 8000 years: the Blake Event at Rutten sets on just before the Eemian does (PAZ E1), and continues into the final phase of the interglacial (across the boundary of PAZ E5 and E6). Through this period, excursional declinations with positive inclinations seem to dominate the paleomagnetic directions in NW Europe during the Blake Event, contrary to other regions of the world where fully reversed directions are predominantly found. This suggests large geographical variability in the behaviour of the Earth's magnetic field during the Blake Event.

The Blake Event is timed to begin ca. $121.5 \mathrm{ka}$ and to last to at least $113.5 \mathrm{ka}$. The Eemian of NW Europe sets on at ca. $121.0 \mathrm{ka}$, just after the onset of the Blake Event. These ages follow from correlations to established age-models for the MD95-2042 site and sapropel S5 in the Eastern Mediterranean and are in agreement with dating of the Blake Event at various marine and terrestrial sites.

\section{Acknowledgements}

We gratefully thank Iuliana Vasiliev for her help and advice, Joanne Porck for figure preparation, Alice Versendaal (WUR-NCL) for luminescence sample preparation and measurements, Heleen Koolmees (TNO-GSN) for pollen analyses, Wim Booltink and Henny Mensink (both TNO-GSN) for core handling and description. Further, this paper benefited from discussions with many colleagues at various stages of the work. The anonymous reviewers and Esther Stouthamer and Hans Middelkoop (both UU) are acknowledged for improving this paper with their valuable comments. The research of Mark Sier was funded by the NWO Spinoza Award (036.001364) to Wil Roebroeks. This paper is also part of Jan Peeters' PhD-research at Utrecht University and is supported by Statoil, TNO-GSN and Deltares. Josep Parés' research was partly funded by grant CGL2010-16821 (MINECO). The WUR-NCL is supported by NWO-ALW investment grant 834.03.003.

\section{Appendix A. Supplementary data}

Supplementary data related to this article can be found at http:// dx.doi.org/10.1016/j.quageo.2015.03.003.

\section{References}

Abrahamsen, N., 1995. Paleomagnetism of Quaternary sediments from anholt Denmark: onset of the blake event and eem. Bull. Geol. Soc. Den. 42, 96-105. Antoine, P., Limondin-Lozouet, N., Auguste, P., 2006. Le tuf de Caours (Somme, France): mise en évidence d'une séquence eemienne et d'un site paléolithique associé. Quaternaire 17, 281-320.

Bakels, C., 2012. Non-pollen palynomorphs from the Eemian pool Neumark-Nord 2: determining water quality and the source of high pollen-percentages of herbaceous taxa. Rev. Palaeobot. Palynol. 186, 58-61. http://dx.doi.org/10.1016/ j.revpalbo.2012.06.003.

Baltrūnas, V., Šeirienè, V., Molodkov, A., Zinkute, R., Katinas, V., Karmaza, B., Kisielienè, D., Petrošius, R., Taraškevičius, R., Piličiauskas, G., Schmölcke, U., Heinrich, D., 2013. Depositional environment and climate changes during the late Pleistocene as recorded by the Netiesos section in southern Lithuania. Quat Int. 292, 136-149. http://dx.doi.org/10.1016/j.quaint.2012.11.038.

Bauch, H., Erlenkeuser, H., Jung, S., Thiede, J., 2000. Surface and deep water changes in the subpolar North Atlantic during Termination II and the last interglaciation. Paleoceanography 15, 76-84.

Bazylinski, D.A., Frankel, R.B., 2004. Magnetosome formation in prokaryotes. Nat. Rev. Microbiol. 2, 217-230. http://dx.doi.org/10.1038/nrmicro842.

Beets, C., Beets, D., 2003. A high resolution stable isotope record of the penultimate deglaciation in lake sediments below the city of Amsterdam, The Netherlands. Quat. Sci. Rev. 22, 195-207.

Beets, D., Beets, C., Cleveringa, P., 2006. Age and climate of the late Saalian and early Eemian in the type-area, Amsterdam basin, The Netherlands. Quat. Sci. Rev. 25, 876-885. http://dx.doi.org/10.1016/j.quascirev.2005.10.001.

Bosch, J.H.A., 2000. Standard Boor Beschrijvingsmethode Versie 5.1 Netherlands Institute of Applied Geosciences TNO. Report NITG 00-141-A.

Bourne, M., Mac Niocaill, C., Thomas, A.L., Knudsen, M.F., Henderson, G.M., 2012. Rapid directional changes associated with a 6.5kyr-long Blake geomagnetic excursion at the Blake-Bahama Outer Ridge. Earth Planet. Sci. Lett. 333-334, 21-34. http://dx.doi.org/10.1016/j.epsl.2012.04.017.

Brauer, A., Allen, J., Mingram, J., Dulski, P., Wulf, S., Huntley, B., 2007. Evidence for last interglacial chronology and environmental change from Southern Europe. Proc. Natl. Acad. Sci. 104 (2), 450-455.

Busschers, F.S., Kasse, C., van Balen, R.T., Vandenberghe, J., Cohen, K.M., Weerts, H.J.T., Wallinga, J., Johns, C., Cleveringa, P., Bunnik, F.P.M., 2007. Late Pleistocene evolution of the Rhine-Meuse system in the southern North Sea basin: imprints of climate change, sea-level oscillation and glacio-isostacy. Quat. Sci. Rev. 26, 3216-3248. http://dx.doi.org/10.1016/j.quascirev.2007.07.013.

Busschers, F.S., Van Balen, R.T., Cohen, K.M., Kasse, C., Weerts, H.J.T., Wallinga, J., Bunnik, F.P.M., 2008. Response of the Rhine-Meuse fluvial system to Saalian icesheet dynamics. Boreas 37, 377-398. http://dx.doi.org/10.1111/j.15023885.2008.00025.X.

Buylaert, J.P., Jain, M., Murray, A.S., Thomsen, K.J., Thiel, C., Sohbati, R., 2012. A robust feldspar luminescence dating method for Middle and Late Pleistocene sediments. Boreas 41, 435-451. http://dx.doi.org/10.1111/j.15023885.2012.00248.x.

Caspers, G., Merkt, J., Müller, H., Freund, H., 2002. The Eemian interglaciation in Northwestern Germany. Quat. Res. 58, 49-52. http://dx.doi.org/10.1006/ qres.2002.2341.

Chang, L., Roberts, A.P., Winklhofer, M., Heslop, D., Dekkers, M.J., Krijgsman, W., Fitz Gerald, J.D., Smith, P., 2014a. Magnetic detection and characterization of biogenic magnetic minerals: a comparison of ferromagnetic resonance and first-order reversal curve diagrams. J. Geophys. Res. Solid Earth 119, 6136-6158. http://dx.doi.org/10.1002/2014JB011213.

Chang, L., Vasiliev, I., Van Baak, C.G.C., Krijgsman, W., Dekkers, M.J., Roberts, A.P., Fitz Gerald, J.D., Van Hoesel, A., Winklhofer, M., 2014b. Identification and environmental interpretation of diagenetic and biogenic greigite in sediments: a lesson from Messinian interval of the Black Sea. Geochem. Geophys. Geosystems 15, 3612-3627.

Channell, J.E.T., Hodell, D., Curtis, J.H., 2012. ODP site 1063 (Bermuda Rise) revisited: oxygen isotopes, excursions and paleointensity in the Brunhes Chron. Geochem. Geophys. Geosys. 13 http://dx.doi.org/10.1029/2011GC003897. Q02001.

Cleveringa, P., Meijer, T., Leeuwen, R.J.W., van, de Wolf, H., Pouwer, R., Lissenberg, T., Burger, A.W., 2000. The Eemian stratotype locality at Amersfoort in the central Netherlands: a re-evalution of old and new data. Geol. Mijnb. 79, 197-216. Retrieved from http://www.researchgate.net/publication/27711153_The Eemian_stratotype_locality_at_Amersfoort_in_the_central_Netherlands_a_reevaluation_of_old_and_new_data/file/6a85e52d662737dd3c.pdf.

Cohen, K.M., Gibbard, P.L., Weerts, H.J.T., 2014. North Sea palaeogeographical reconstructions for the last 1 Ma North Sea palaeogeographical reconstructions for the last 1 Ma. Neth. J. Geosci. 2014, 1-23. http://dx.doi.org/10.1017/ njg.2014.12. 
Dankers, P., Zijderveld, J., 1981. Alternating field demagnetization of rocks, and the problem of gyromagnetic remanence. Earth Planet. Sci. Lett. 53, 89-92.

De Gans, W., Beets, D.J., Centineo, M.C., 2000. Late Saalian and Eemian deposits in the Amsterdam glacial basin. Geol. Netherl. Geosci. 79, 147-160.

Egli, R., 2004. Characterization of individual rock magnetic components by analysis of remanence curves. 3. Bacterial magnetite and natural processes in lakes. Phys. Chem. Earth, Parts A/B/C 29, 869-884. http://dx.doi.org/10.1016/ j.pce.2004.03.010.

Egli, R., Chen, A.P., Winklhofer, M., Kodama, K.P., Horng, C.-S., 2010. Detection of noninteracting single domain particles using first-order reversal curve diagrams. Geochem. Geophys. Geosystems 11. http://dx.doi.org/10.1029/ 2009GC002916.

Gaigalas, A., Arslanov, K.A., Maksimov, F.E., Kuznetsov, V.Y., Chernov, S.B., 2005. Results of uranium-thorium isochron dating of Netiesos section peat-bog in South Lithuania. Geologija 51, 29-38.

Gaigalas, A., Molodkov, A., 2002. ESR ages of three Lithuanian Mid-Late Pleistocene Interglacials: methodical and stratigraphical approach. Geochronometria 21, 57-64.

Gibbard, P.L., 2003. Definition of the Middle-Upper pleistocene boundary. Glob. Planet. Change 36, 201-208. http://dx.doi.org/10.1016/S0921-8181(02)00185-6.

Gibbard, P.L., Cohen, K.M., 2008. Global chronostratigraphical correlation table for the last 2.7 million years. Episodes 31, 243-247.

Gunnink, J.L., Maljers, D., Gessel, S.F. Van, Menkovic, A., Hummelman, H.J., 2013 Digital Geological Model (DGM): a 3D raster model of the subsurface of the Netherlands. Neth. J. Geosci. 92, 33-46.

Hahne, J., Kemle, S., Merkt, J., Meyer, K., 1994. Eem-, weichsel-und saalezeitliche Ablagerungen der Bohrung "Quakenbrück GE 2." Geol. Jahrb. A134, 9-69.

Harting, P., 1874. De bodem van het Eemdal. Versl. en Verh. K. Akad. van Wet, pp. $282-290$

Head, M., Zalasiewicz, J., Cohen, K., van Kolfschoten, T., Kalnina, L., Voelker, A Negri, A., Lirer, F., Ciaranfi, N., Suganuma, Y., Kazaoka, O., Gladenkov, Y. Morard, A., Miura, H., Agnini, C., Raffi, I., di Stefano, A., 2013. Report on an Open Business Meeting, 5 July 2013, During the STRATI 2013 Meeting. Subcommis sion on Quaternary Stratigraphy, International Commission on Stratigraphy.

Helmens, K.F., 2014. The last interglacial-glacial cycle (MIS 5-2) re-examined based on long proxy records from central and northern Europe. Quat. Sci. Rev. 86, 115-123. http://dx.doi.org/10.1016/j.quascirev.2013.12.012.

Heslop, D., Mcintosh, G., Dekkers, M.J., 2004. Using time- and temperaturedependent Preisach models to investigate the limitations of modelling isothermal remanent magnetization acquisition curves with cumulative log Gaussian functions. Geophys. J. Int. 157, 55-63. http://dx.doi.org/10.1111/j.1365246X.2004.02155.x.

Jessen, K., Milthers, V., 1928. Stratigraphical and paleontological studies of interglacial freahwater deposits in Jutland and Northwest Germany. Danmarks Geol. Undersoeglse 48.

Kars, R.H., Busschers, F.S., Wallinga, J., 2012. Validating post IR-IRSL dating on Kfeldspars through comparison with quartz OSL ages. Quat. Geochronol. 12, 74-86. http://dx.doi.org/10.1016/j.quageo.2012.05.001.

Kirschvink, J., 1980. The least-square line and plane and the analysis of paleomagnmetic data. Geophys. J. R. Astron. Soc. 62, 699-718.

Kruiver, P.P., Dekkers, M.J., Heslop, D., 2001. Quantification of magnetic coercivity components by the analysis of acquisition curves of isothermal remanent magnetisation. Earth Planet. Sci. Lett. 189, 269-276.

Kukla, G.J., de Beaulieu, J.-L., Svobodova, H., Andrieu-Ponel, V., Thouveny, N., Stockhausen, H., 2002. Tentative correlation of pollen records of the last interglacial at Grande Pile and Ribains with Marine isotope stages. Quat. Res. 58, 32-35. http://dx.doi.org/10.1006/qres.2002.2340.

Laban, C., van der Meer, J.J.M., 2011. Pleistocene Glaciation in The Netherlands. Developments in Quaternary Science. Elsevier Inc. http://dx.doi.org/10.1016 B978-0-444-53447-7.00020-9.

Lee, J.R., Busschers, F.S., Sejrup, H.P., 2012. Pre-Weichselian Quaternary glaciations of the British Isles, The Netherlands, Norway and adjacent marine areas south of $68^{\circ} \mathrm{N}$ : implications for long-term ice sheet development in northern Europe. Quat. Sci. Rev. 44, 213-228. http://dx.doi.org/10.1016/j.quascirev.2010.02.027.

Lee, M., Wei, K., Chen, Y., 1999. High resolution oxygen isotope stratigraphy for the last 150,000 years in the southern South China Sea: core MD972151. Terr. A. T. Ocean. Sci. 10, 239-254.

Lee, T., 1999. Last 160 ka paleomagnetic directional secular variation record from core MD972151, southwestern South China Sea. Terr. A. T. Ocean. Sci. 10 255-264.

Lisiecki, L.E., Raymo, M.E., 2005. A Pliocene-Pleistocene stack of 57 globally distributed benthic $\delta{ }^{18} \mathrm{O}$ records. Paleoceanography. http://dx.doi.org/10.1029/ 2004PA001071.

Litt, T., Gibbard, P., 2008. Definition of a global stratotype section and Point (GSSP) for the base of the upper (Late) pleistocene Subseries (Quaternary System Period). Episodes 1, 260-263.

Lowe, J.J., Rasmussen, S.O., Björck, S., Hoek, W.Z., Steffensen, J.P., Walker, M.J.C. $\mathrm{Yu}, \mathrm{Z}$.C., the INTIMATE Group, 2008. Synchronisation of palaeoenvironmental events in the North Atlantic region during the Last Termination: a revised protocol recommended by the INTIMATE group. Quat. Sci. Rev. 27, 6-17. http:/ dx.doi.org/10.1016/j.quascirev.2007.09.016.

Menke, B., Tynni, R., 1984. Das Eeminterglazial und Weichselfrühglazial von Rederstall/Dittmarschen und ihre Bedeutung für die mitteleuropäische Jungpleistozän Gliederung. Geol. Jahrb. A76, 3-120.

Merril, R.T., McFadden, P.L., 1994. Geomagnetic field stability: reversal events and excursions. Earth Planet. Sci. Lett. 121, 57-69.

Müller, H., 1974. Pollenanalytische Untersuchungen und Jahresschichtenzählungen an der eem-zeitlichen Kieselgur von Bispingen/Luhe. Geol. Jahrb. A21, 149-169.

NEEM community Members, 2013. Eemian interglacial reconstructed from a Greenland folded ice core. Nature 493, 489-494.

Newell, A.J., 2005. A high-precision model of first-order reversal curve (FORC) functions for single-domain ferromagnets with uniaxial anisotropy. Geochem. Geophys. Geosystems 6. http://dx.doi.org/10.1029/2004GC000877.

North Greenland Ice Core Project members, 2004. High-resolution record of Northern Hemisphere climate extending into the last interglacial period. Nature 431 (7005), 147-151. http://dx.doi.org/10.1038/nature02805.

Nowaczyk, N.R., Frederichs, T.W., Eisenhauer, A., Gard, G., 1994. Magnetostratigraphic data from late Quaternary sediments from the Yermak Plateau, Artic Ocean: evidence for four geomagnetic polarity events within the last $170 \mathrm{Ka}$ of the Brunhes Chron. Geophys. J. Int. 117, 453-471.

Osete, M.-L., Martín-Chivelet, J., Rossi, C., Edwards, R.L., Egli, R., Muñoz-García, M.B., Wang, X., Pavón-Carrasco, F.J., Heller, F., 2012. The Blake geomagnetic excursion recorded in a radiometrically dated speleothem. Earth Planet. Sci. Lett. 353-354, 173-181. http://dx.doi.org/10.1016/j.epsl.2012.07.041.

Passchier, S., Laban, C., Mesdag, C.S., Rijsdijk, K.F., 2010. Subglacial bed conditions during Late Pleistocene glaciations and their impact on ice dynamics in the southern North Sea. Boreas 2010, 633-647. http://dx.doi.org/10.1111/j.15023885.2009.00138.x.

Peeters, J., Busschers, F.S., Stouthamer, E., 2015. Fluvial evolution of the Rhine during the last interglacial-glacial cycle in the southern North Sea basin: a review and look forward. Quat. Int. 357, 176-188. http://dx.doi.org/10.1016/ j.quaint.2014.03.024.

Pike, C.R., Roberts, A.P., Verosub, K.L., 1999. Characterizing interactions in fine magnetic particle systems using first order reversal curves. J. Appl. Phys. 85, 6660-6667. http://dx.doi.org/10.1063/1.370176.

Rasmussen, S.O., Bigler, M., Blunier, T., Buchardt, S.L., Clausen, H.B., Cvijanovic, I., Johnsen, S.J., Fischer, H., Gkinis, V., Guillevic, M., Hoek, W.Z., Lowe, J.J., Pedro, J., Popp, T., Seierstad, I.K., Steffensen, J.P., Svensson, A.M., Vallelonga, P., Vinther, B.M., Wheatley, J.J., Winstrup, M., 2014. A stratigraphic framework for robust naming and correlation of abupt climatic changes during the last glacial period based on three synchronized Greenland ice core records. Quat. Sci. Rev. 106, 14-28. http://dx.doi.org/10.1016/j.quascirev.2014.09.007.

Renssen, H., Seppä, H., Crosta, X., Goosse, H., Roche, D.M., 2012. Global characterization of the holocene thermal maximum. Quat. Sci. Rev. 48, 7-19. http:// dx.doi.org/10.1016/j.quascirev.2012.05.022.

Roberts, A., Chang, L., Rowan, C.J., Horng, C.-S., 2011. Magnetic properties of sedimentary greigite (Fe3S4): an update. Rev. Geophys. 49 http://dx.doi.org/ 10.1029/2010RG000336.1.INTRODUCTION.

Roberts, A.P., Liu, Q., Rowan, C.J., Chang, L., Carvallo, C., Torrent, J., Horng, C.-S., 2006 Characterization of hematite ( $\alpha$-Fe 203 ), goethite $(\alpha-\mathrm{FeOOH})$, greigite (Fe $3 \mathrm{~S}$ 4 ), and pyrrhotite (Fe $7 \mathrm{~S} 8$ ) using first-order reversal curve diagrams. J. Geophys. Res. 111, B12S35. http://dx.doi.org/10.1029/2006JB004715.

Roberts, A.P., Pike, C.R., Verosub, K.L., 2000. First-order reversal curve diagrams: a new tool for characterizing the magnetic properties of natural samples. J. Geophys. Res. 105, 28461. http://dx.doi.org/10.1029/2000JB900326.

Roberts, A.P., Weaver, R., 2005. Multiple mechanisms of remagnetization involving sedimentary greigite (Fe3S4). Earth Planet. Sci. Lett. 231, 263-277. http:// dx.doi.org/10.1016/j.epsl.2004.11.024

Rowan, C.J., Roberts, A.P., 2006. Magnetite dissolution, diachronous greigite formation, and secondary magnetizations from pyrite oxidation: Unravelling complex magnetizations in Neogene marine sediments from New Zealand. Earth Planet. Sci. Lett. 241, 119-137. http://dx.doi.org/10.1016/j.epsl.2005.10.017.

Sagnotti, L., Cascella, A., Ciaranfi, N., Macrì, P., Maiorano, P., Marino, M., Taddeucci, J., 2010. Rock magnetism and palaeomagnetism of the Montalbano Jonico section (Italy): evidence for late diagenetic growth of greigite and implications for magnetostratigraphy. Geophys. J. Int. 180, 1049-1066. http://dx.doi.org/10.1111/ j.1365-246X.2009.04480.x.

Sánchez Goñi, M., Eynaud, F., Turon, J., Shackleton, N.J., 1999. High resolution palynological record off the Iberian margin: direct land-sea correlation for the Last Interglacial complex. Earth Planet. Sci. Lett. 171, 123-137.

Scholger, R., Terhorst, B., 2013. Magnetic excursions recorded in the Middle to Upper Pleistocene loess/palaeosol sequence Wels-Aschet (Austria). E G. Quat. Sci. J. 62, 14-21. http://dx.doi.org/10.3285/eg.62.1.02.

Shackleton, N.J., Chapman, M., Sánchez-Goñi, M.F., Pailler, D., Lancelot, Y., 2002. The Classic Marine Isotope Substage 5e. Quat. Res. 58, 14-16. http://dx.doi.org/ 10.1006/qres.2001.2312.

Shackleton, N.J., Sánchez Goñi, M.F., Pailler, D., Lancelot, Y., 2003. Marine isotope substage 5e and the Eemian interglacial. Glob. Planet. Change 36, 151-155. http://dx.doi.org/10.1016/S0921-8181(02)00181-9.

Sier, M.J., Dekkers, M.J., 2013. Magnetic property analysis as palaeoenvironmental proxy: a case study of the Last Interglacial Middle Palaeolithic site at NeumarkNord 2 (Germany). In: Gaudzinski-Windheuser, S., Roebroeks, W. (Eds.), Multidisciplinary Studies of the Middle Palaeolithic Record from Neumark-nord (Germany). LDASA, Halle, pp. 117-130.

Sier, M.J., Parés, J.M., Antoine, P., Locht, J.-L., Dekkers, M.J., Limondin-Lozouet, N., Roebroeks, W., 2015. Evidence for the Blake event recorded at the Eemian archaeological site of Caours, France. Quat. Int. 357, 149-157. http://dx.doi.org/ 10.1016/j.quaint.2014.05.022.

Sier, M.J., Roebroeks, W., Bakels, C.C., Dekkers, M.J., Brühl, E., De Loecker, D., Gaudzinski-Windheuser, S., Hesse, N., Jagich, A., Kindler, L., Kuijper, W.J., 
Laurat, T., Mücher, H.J., Penkman, K.E.H., Richter, D., van Hinsbergen, D.J.J., 2011. Direct terrestrial-marine correlation demonstrates surprisingly late onset of the last interglacial in central Europe. Quat. Res. 75, 213-218. http://dx.doi.org/ 10.1016/j.yqres.2010.11.003.

Sirocko, F., Seelos, K., Schaber, K., Rein, B., Dreher, F., Diehl, M., Lehne, R., Jäger, K., Krbetschek, M., Degering, D., 2005. A late Eemian aridity pulse in central Europe during the last glacial inception. Nature 436, 833-836. http://dx.doi.org/ 10.1038 /nature03905.

Smith, J., Foster, J., 1969. Geomagnetic Reversal in Brunhes Normal Polarity Epoch.

Stephenson, A., 1993. Three-axis static alternating field demagnetization of rocks and the identification of natural remanent magnetization, gyroremanent magnetization, and anisotropy. J. Geophys. Res. Solid Earth 98, 373-381.

Tauxe, L., Mullender, T., Pick, T., 1996. Potbellies, wasp-waists, and superparamagnetism in magnetic hysteresis. J. Geophys. Res. 101, 571-583.

Thiel, C., Buylaert, J.-P., Murray, A., Terhorst, B., Hofer, I., Tsukamoto, S., Frechen, M., 2011. Luminescence dating of the Stratzing loess profile (Austria) - testing the potential of an elevated temperature post-IR IRSL protocol. Quat. Int. 234, 23-31. http://dx.doi.org/10.1016/j.quaint.2010.05.018.

Thouveny, N., 2004. Palaeomagnetic (On $8 \mathrm{Cm}^{* * 3}$ Samples) of Sediment Core MD95-2042 [WWW Document]. http://dx.doi.org/10.1594/PANGAEA.207910.

Thouveny, N., Carcaillet, J., Moreno, E., Leduc, G., Nérini, D., 2004. Geomagnetic moment variation and paleomagnetic excursions since 400 kyr BP: a stacked record from sedimentary sequences of the Portuguese margin. Earth Planet. Sci. Lett. 219, 377-396. http://dx.doi.org/10.1016/S0012-821X(03)00701-5.

Tric, E., Laj, C., Valet, J., Tucholka, P., Peterne, M., Guichard, F., 1991. The Blake geomagnetic event: transition geometry, dynamical characteristics and geomagnetic significance. Earth Planet. Sci. Lett. 102, 1-13.

Tucholka, P., Fontugne, M., Guichard, F., Paterne, M., 1987. The Blake magnetic polarity episode in cores from the Mediterranean Sea. Earth Planet. Sci. Lett. 86, $320-326$.

Turner, C., 2000. The Eemian interglacial in the North European plain and adjacent areas. Geol. Netherl. Geosci. 79, 217-231.

Turner, C., 2002a. Formal status and vegetational development of the eemian interglacial in Northwestern and southern europe. Quat. Res. 58, 41-44. http:/ dx.doi.org/10.1006/qres.2002.2365.

Turner, C., 2002b. Problems of the duration of the Eemian Interglacial in Europe North of the Alps. Quat. Res. 58, 45-48. http://dx.doi.org/10.1006/ qres.2002.2366.

Tzedakis, C., 2003. Timing and duration of Last Interglacial conditions in Europe: a chronicle of a changing chronology. Quat. Sci. Rev. 22, 763-768. http:// dx.doi.org/10.1016/S0277-3791(03) 00004-0.
Tzedakis, P.C., Frogley, M.R., Heaton, T.H.E., 2003. Last interglacial conditions in southern Europe: evidence from Ioannina, northwest Greece. Glob. Planet. Change 157-170. http://dx.doi.org/10.1016/S0921-8181(02)00182-0.

Van den Berg, M.W., Beets, D.J., 1987. Saalian glacial deposits and morphology in The Netherlands. In: Meer, van der, J.J. (Eds.), INQUA Symposium on the Genesi and Lithology of Glacial Deposits. Balkema, Amsterdam, pp. 235-251.

Van Huissteden, K., Vandenberghe, J., Pollard, D., 2003. Palaeotemperature reconstructions of the European permafrost zone during marine oxygen isotope stage 3 compared with climate model results. J. Quat. Sci. 18, 453-464. http:// dx.doi.org/10.1002/jqs.766.

Van Leeuwen, R., Beets, D., Bosch, J., Burger, A., Cleveringa, P., van Harten, D., Waldemar Herngreen, G., Kruk, R., Langereis, C., Meijer, T., Pouwer, R., de Wolf, $H_{\text {. }}$ 2000. Stratigraphy and integrated facies analysis of the Saalian and Eemian sediments in the Amsterdam-Terminal borehole, the Netherlands. Neth. J. Geosci. 79, 161-196.

Vasiliev, I., Dekkers, M.J., Krijgsman, W., Franke, C., Langereis, C.G., Mullender, T. a. T. 2007. Early diagenetic greigite as a recorder of the palaeomagnetic signal in Miocene-Pliocene sedimentary rocks of the Carpathian foredeep (Romania) Geophys. J. Int. 171, 613-629. http://dx.doi.org/10.1111/j.1365246X.2007.03560.x.

Vasiliev, I., Franke, C., Meeldijk, J.D., Dekkers, M.J., Langereis, C.G., Krijgsman, W., 2008. Putative greigite magnetofossils from the Pliocene epoch. Nat. Geosci. 1 , 782-786. http://dx.doi.org/10.1038/ngeo335.

Wintle, A.G., Murray, A.S., 2006. A review of quartz optically stimulated luminescence characteristics and their relevance in single-aliquot regeneration dating protocols. Radiat. Meas. 41, 369-391. http://dx.doi.org/10.1016 j.radmeas.2005.11.001.

Wollin, G., Ericson, D.B., Ryan, W.B.F., Foster, J.H., 1971. Magnetism of the earth and climatic changes. Earth Planetary Sci. Lett. 12, 175-183.

Zagwijn, W.H., 1961. Vegetation, climate and radiocarbond datings in the late Pleistocene of the Netherlands:I. Eemien and early Weicheselian. Meded. Geol. Sticht. Nieuwe Ser 14, 15-45.

Zagwijn, W.H., 1974. The palaeogeographic evolution of the Netherlands during the Quaternary. Geol. Mijnb 53, 369-385.

Zagwijn, W.H., 1983. Sea-level changes in the netherlands during the eemian. Geol Mijnb 62, 437-450.

Zagwijn, W.H., 1996. An analysis of Eemian climate in western and central Europe. Quat. Sci. Rev. 15, 451-469.

Ziegler, M., Tuenter, E., Lourens, L.J., 2010. The precession phase of the boreal summer monsoon as viewed from the eastern Mediterranean (ODP site 968). Quat. Sci. Rev. 29, 1481-1490. http://dx.doi.org/10.1016/j.quascirev.2010.03.011. 